\title{
Aspects of mast building and the fine structure of "amphipod silk" glands in Dyopedos bispinis (Amphipoda, Dulichiidae)
}

\author{
Nikolai Y. Neretin ${ }^{1,3}$, Anna E. Zhadan ${ }^{1}$, Alexander B. Tzetlin ${ }^{1,2}$ \\ ${ }^{1}$ Pertsov White Sea Biological Station, Biological Faculty, Moscow State University, 119991, Leninskie gori 1/12, \\ Moscow, Russia \\ ${ }^{2}$ Department of Invertebrate Zoology, Biological Faculty, Moscow State University, 119991, Leninskie gori 1/12, \\ Moscow, Russia \\ ${ }^{3}$ E-mail:dulichii@yandex.ru
}

Key words: amphipod masts, amphipod silk, amphipod whips, Dulichiidae, Dyopedos bispinis, extended parental care, mast building, pereopods 3-4, tegumental glands

\begin{abstract}
In the present study, we investigated the biology of Dyopedos bispinis, a mast-building amphipod that is abundant near the $\mathrm{N}$. Pertsov White Sea Biological Station. To examine the peculiarities of mast building in Dyopedos bispinis, we studied the social structure of individuals inhabiting the masts and identified the preferred substrata through underwater photography and direct observations, characterized the internal and external structures of the masts, and studied the ultrastructure of pereopodal silk glands using scanning and transmission electron microscopy (SEM and TEM, respectively). The most frequent substrata for mast building are other fouling organisms, including hydroids, bryozoans, ascidians and sponges. As in other corophiids, each Dyopedos bispinis mast represents the territory of one female and, occasionally, one male, but unique collective masts occupied by three or more (up to 23) adults were also observed. Masts comprise one or 2-4 central cylinders and a laminated cortex that contains detritus and amphipod silk layers. The pereopodal glandular complex of Dyopedos bispinis is composed of two distinct gland groups, proximal and distal, in each pereopod 3-4, and ducts in the glandular complex lead into a common chamber in the dactylus. The proximal glands are multicellular; their secretory cells are uninuclear, unlike in certain other amphipods; and the cell membrane is deeply invaginated. The invaginations are filled with extensions of the cytoplasm of lining cells, but the origin of the lining is unclear. Axon terminals were observed adjacent to the secretory cells, and it is assumed that these axons regulate amphipod silk glands. The proximal silk glands of Dyopedos bispinis have similarities with the lobed and rosette glands of isopods, but they have strongly elongated forms. We refer to these glands as pseudotubular glands. Such glands are rarely observed in Crustacea and have only been described in silk-producing pereopodal systems of marine Peracarida and in the antenna of terrestrial Malacostraca.
\end{abstract}

\section{Contents}

Introduction 145

Material and methods 147

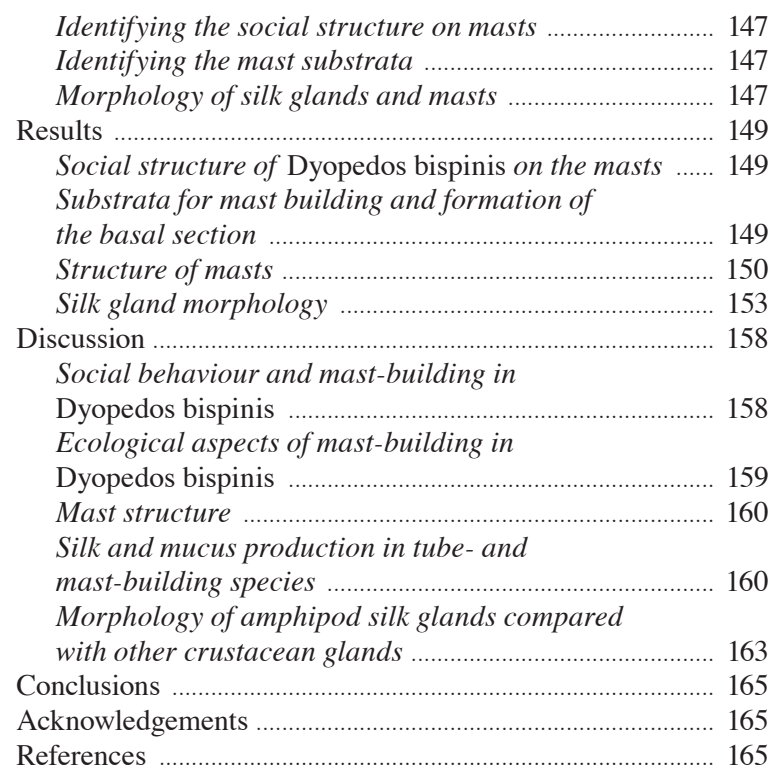

\section{Introduction}

Many amphipods are able to construct dwellings and make various burrows, tubes and masts (Atkinson and Eastman, 2015; Moore and Eastman, 2015). Masts, which are also known as whips and rods, are thin, flexible vertical structures that are attached to the substrate at one end, and they improve filter-feeding efficiency by elevating the amphipod above the seabed to heights more than 10 times their body length (Mattson and Cedhagen, 1989). It has also been suggested that mast building provides protection from predation (Mattson and Cedhagen, 1989, Thiel, 1999). Furthermore, amphipods exhibit complex territorial behaviour and obligate extended parental care, which is unusual for most 
tube-building amphipods (Mattson and Cedhagen, 1989; Thiel, 1997, 1998a, 1998b, 1999). Additionally, masts can be used by amphipods to cultivate diatoms (McCloskey, 1970).

Amphipods build masts on different substrates in various biotopes. Dulichia rhabdoplastis, McCloskey, 1970 build masts on the spines of sea urchins; Dyopedos monacantha (Metzger, 1875) prefer soft bottoms; whereas Dyopedos porrectus Bate, 1857 typically live on hard bottoms and associate with hydroids (McCloskey, 1970; Moore and Earll, 1985; Mattson and Cedhagen, 1989; Thiel, 1998b). In certain biotopes, mastbuilding amphipods are abundant; the density of $D y$ opedos monacantha reaches more than 3000 individuals per square metre (Thiel, 1998b) while that of $D y$ opedos bispinis masts in the White Sea can exceed 2000 per square metre (Zhadan et al., 2007). However, little is known regarding the influence of mast-building on benthic communities.

The social structures of masts were studied in $D y$ opedos monacantha in aquaria and under natural conditions (Mattson and Cedhagen, 1989; Thiel, 1997, 1998a, 1998b, 1999). Each mast belongs to a juvenile amphipod or one adult female and is the territory of that individual. Juveniles remain on their mother's mast, and members of two consecutive clutches can be present, but it is unknown whether they participate in mast building. Adult males do not build their own masts but participate in the maintenance of the masts of females. While the social structure of other mast-building amphipods has rarely been studied (McCloskey, 1970; Moore and Earll, 1985; Mattson and Cedhagen, 1989), it can differ from that of Dyopedos monacantha; for example, adult male Dyopedos porrectus build their own masts.

In contrast, with epibenthic amphipod tubes, which are relatively short, i.e., rarely greater than 3-4 amphipod body lengths (Shillaker and Moore, 1978; Dixon and Moore, 1997), masts are large-scale structures. Masts built by the amphipod Dyopedos bispinis Gurjanova, 1930 in the White Sea can reach 10 and occasionally even $20 \mathrm{~cm}, 20$ and 40 times longer than the length of an adult female, respectively (our unpublished data). Mattson and Cedhagen (1989) observed mast building in Dyopedos monacantha and Dyopedos porrectus in aquariums and found that amphipods fasten detritus together using mucus threads produced by the gnathopods and mouthparts, and the detritus is subsequently covered with silk threads from the pereopods. Detritus collection methods (from the water column and from the bottom) vary in different species and in different conditions (Mattson and Cedhagen, 1989). Scanning electron microscopy (SEM) was used to characterize the silk network on the surface of the $D y$ opedos porrectus mast (Moore and Earll, 1985), but the internal structure of masts has not been studied in detail. Therefore, the proportions of mouthpart secretion, pereopodal secretion and detritus in the mast remain unclear.

To build masts and tubes, amphipods use special secretions that are typically called "amphipod silk" (Smith, 1874; Goodhart, 1939; Dixon and Moore, 1997; Cerda et al., 2010, Kronenberger et al., 2012a,b). In some cases, this secretion is a mucus cement (Goodhart, 1939), but in most amphipod species, it is produced in the form of threads (Skutch, 1926; Shillaker and Moore, 1978; Moore and Earll, 1985; Barnard et al., 1988; Mattson and Cedhagen, 1989; Cerda et al., 2010; Zorn et al., 2010; Kronenberger et al., 2012a). Generally, silks are defined as protein polymers produced and spun into fibres by various arthropods (Altman et al., 2003; Sutherland et al., 2010). Insect and spider silks are well known and are currently subject to intense biochemical studies (Kovoor, 1987; Foelix, 2010; Sutherland et al., 2010; Kundu et al., 2014). Certain crustaceans (belonging to Amphipoda, Tanaidacea, Ostracoda and Decapoda) also produce silk-like materials (Wouters and De Grave, 1992; Dworschak, 1998; Kronenberger et al., 2012a; Kakui and Hiruta, 2014), but their chemical structure and the morphology of the silk glands are poorly known. Currently, only one crustacean silk from the amphipod Crassicorophium bonellii (Milne Edwards, 1830) has been chemically investigated (Kronenberger et al. 2012a).

Amphipod silk is secreted from a special large glandular complex located in pereopods $3-4$, and the presence of such complexes has been described in most corophiid families and in the family Ampeliscidae (Myers and Lowry, 2003; Cadien, 2015). Nebeski (1880) described the structure of the glandular complex in pereopods 3-4 of Jassa falcata (Montagu, 1808) and certain other tube-building corophiid species. The findings showed that each pereopod contains two gland groups (proximal and distal) that stain differently as well as a common reservoir and a single opening in the dactylus tip. The glands, which belong to the proximal group, have an elongated form and are multicellular, comprising secretory cells that lie along ducts. The ductules from each secretory cell communicate with these ducts individually and in sequence. The glands of another distal group can be unicellular or similar to the proximal glands. Kronenberger et al. (2012b) inves- 
tigated silk glands in Crassicorophium bonellii and Lembos websteri Bate, 1857 and found that the proximal gland group presents rosette glands, while the distal group presents lobed glands. Thus, the structure of amphipod silk glands varies in different species but has never been studied in mast-building amphipods.

The vast majority of builder amphipods construct tubes and burrows, whereas mast building has only been described in four species of the corophiid family Dulichiidae and has not been observed in other crustaceans (McCloskey, 1970; Moore and Earll, 1985; Mattson and Cedhagen, 1989; Zhadan et al., 2007; Moore and Eastman, 2015). Dyopedos bispinis is a polar amphipod that has been detected in several arctic seas, both Eurasian and American, and in the eastern Pacific (Laubitz, 1977). Abundant Dyopedos bispinis masts were recently detected in the Velikaya Salma Strait (White Sea) (Zhadan et al, 2007), but nothing is known regarding the biology and mast-building activity of this species.

\section{Materials and Methods}

\section{Identifying the social structure on masts}

To examine the territorial behaviour and social structure of Dyopedos bispinis on masts, 285 photos were obtained in July 2012 in various biotopes in the White Sea (Kandalaksha Gulf, Velikaya Salma Strait 66.55$66.56^{\circ} \mathrm{N}, 33.09-33.12^{\circ} \mathrm{E}$, depth 8-15 m). Before the photographs were taken, a ruler with 1-mm divisions was placed on the bottom. From the photographs, the numbers of adult males, females and juveniles were counted on each inhabited mast that was in focus (790 masts), and the proportions of masts with one, two, or more than two adult amphipods were calculated. Adult amphipods were distinguished by their length (approximately $5 \mathrm{~mm}$ ), specific body form (slender body and curved back) and brighter coloration, and adult males were identified by their strongly enlarged second gnathopods. In the cases when the maturity of the amphipods could not be accurately determined, the masts were not included in the analysis.

Over 10 dives, all masts with 3 and more adult residents were collected; the masts were plucked with forceps near the mast base and carefully placed in individual tubes that were immediately closed. In the lab, the specimens were fixed in $96 \%$ ethanol, and the amphipods on each mast were counted as described above. Collected such method adult females were distinguished by the presence of oostegites and often by the presence of eggs in the marsupium, males were identified by enlarged second gnathopods. A total of five masts were collected.

\section{Identifying the mast substrata}

To identify the substrata of Dyopedos bispinis masts, underwater observations were performed during 10 dives, and the numbers of masts attached to different types of substrata were counted inside a $0.2-\mathrm{m} \times 0.2-\mathrm{m}$ square frame. For a more detailed assessment, all masts inside 2 survey frames were collected in jars using forceps and a trowel and examined by binocular microscopy. Subsequently, the proportions of masts associated with each substratum were defined, and the substratum was defined for approximately 350 whips. When in focus (210 masts), the substrata were also identified from photos (see above).

\section{Morphology of silk glands and masts}

\section{Specimen collection and fixation}

Material was collected from the White Sea (Kandalaksha Gulf, Velikaya Salma Strait $66.55-66.56^{\circ}$ N, 33.09$33.12^{\circ} \mathrm{E}$, depth $8-15 \mathrm{~m}$ ) in July 2012 by SCUBA diving. Masts with amphipods were plucked using forceps and carefully placed in glass jars, and pereopods 3-4 were detached from the amphipod body and fixed in $2.5 \%$ glutaraldehyde in $0.1 \mathrm{M}$ sodium cacodylate and then post-fixed in osmium tetroxide $\left(\mathrm{OsO}_{4}\right)$. Before or after the first glutaraldehyde fixation, an incision was made on the pereopods, and they were dissected into 2-3 fragments using a razor blade (after Kronenberger et al., 2012a,b) for better penetration. The samples were then dehydrated in an ethanol series and embedded in epoxy resin (Epon 812). For transmission electron microscopy (TEM), the masts were fixed as above, and for light microscopy and SEM, they were fixed in $10 \%$ formalin in seawater ( $4 \%$ formaldehyde).

\section{Light microscopy}

Serial semi-thin sections $(0.9 \mathrm{~mm})$ of masts and pereopod fragments were cut using DuPont MT 5000 and LKB-III microtomes followed by staining with a mixture of methylene blue and toluidine blue. The pereopod sections were examined using a Carl Zeiss Axioplan 2 imaging light microscope, and the masts sections were examined using a Leica DM 2500 microscope. Digital images were captured using an AxioCam HRm camera for pereopods and a Leica DFC 


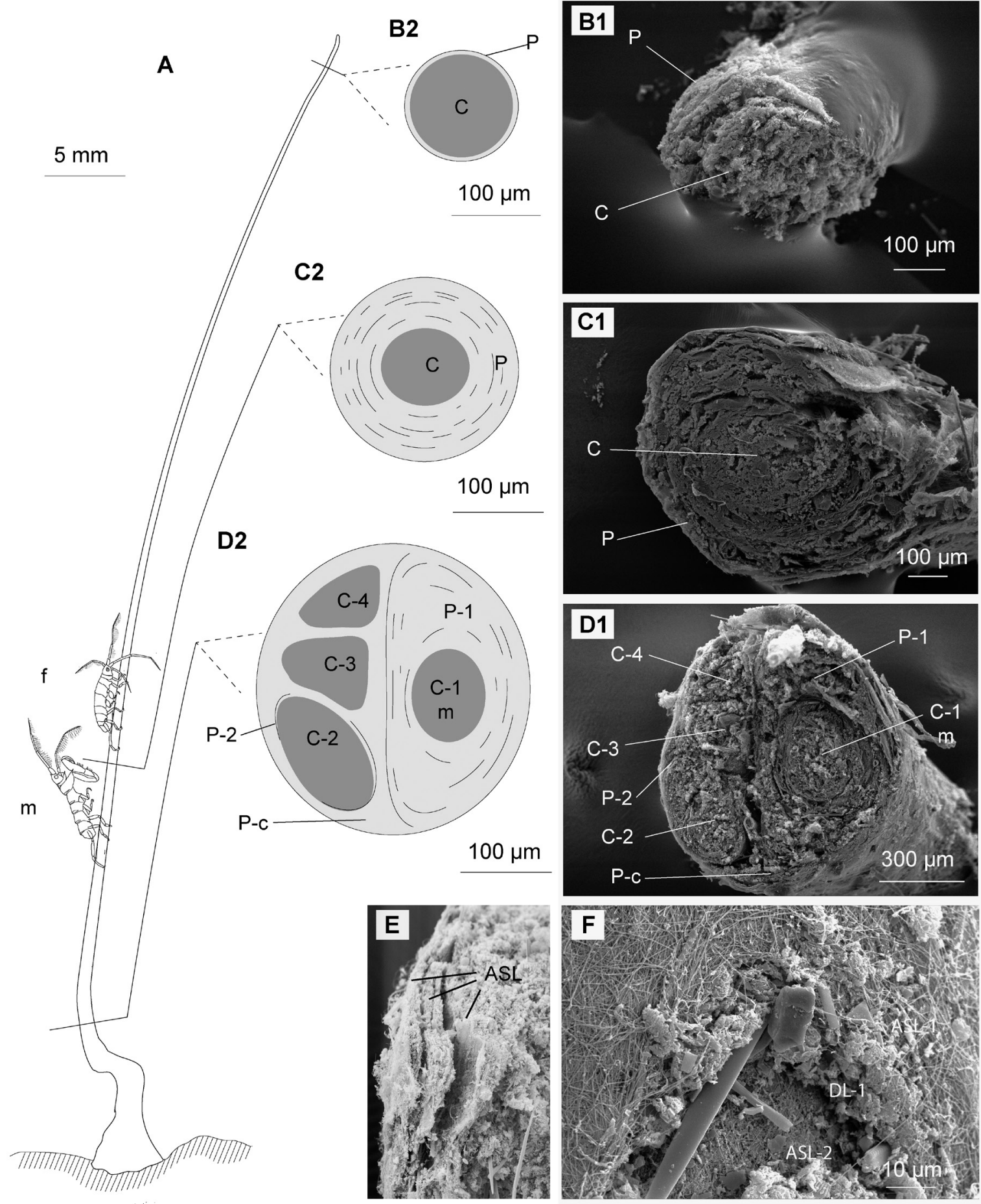

Fig. 1. Internal structure of a Dyopedos bispinis mast. A - drawing of a Dyopedos bispinis mast. B1, C1 and D1 - scanning electron microscopy (SEM) micrographs of mast cross sections at different levels; B2, C2 and D2 - their schematic representations. E and F SEM micrographs of masts with damaged cortexes, showing that the cortex always comprises amphipod silk layers and, sometimes, detritus layers. Abbreviations: ASL, ASL-1, and ASL-2 - silk layers of the laminated cortex; C - central cylinder of the mast; C-1 m - the main cylinder; C-2, C-3, C-4 - additional cylinders; DL-1 - detritus layer of the laminated cortex; f - Dyopedos bispinis female; $\mathrm{m}$ Dyopedos bispinis male; P - laminated cortex of the mast; P-1 - laminated cortex of the main cylinder; P-2 - laminated cortex of an additional cylinder; $\mathrm{P}-\mathrm{c}$ - laminated cortex covering all cylinders. 
290 camera for masts. Serial images were aligned using Amira 5.3.2. Altogether, 4 pereopod and 2 mast fragments were dissected.

The lengths and widths of the collected masts were measured using a ruler and micrometre eyepiece scale; a total of 146 masts were analysed.

\section{Transmission electron microscopy}

Ultra-thin sections were cut using a Leica Ultramicrotome, collected on formvar-covered single slot copper grids, stained with uranyl acetate and lead citrate, and examined with a JEOL JEM-1011 electron microscope.

\section{Scanning electron microscopy}

The fragments of 4 masts were dehydrated in an ethanol-acetone series, critical point dried with $\mathrm{CO}_{2}$ in a Hitachi HCP-2, mounted on aluminium stubs, and sputter-coated with an Au-Pd mixture using an Eiko IB-3 ion coater. To examine the internal structure, thick mast sections $(0.5-2 \mathrm{~mm})$ were cut using razor blades prior to dehydration, and for one mast (approximate length of $70 \mathrm{~mm}$ ), serial sections were generated (each $5-15 \mathrm{~mm}$ ). The specimens were examined using a Cam Scan S-2 scanning electron microscope.

\section{Results}

\section{Social structure of Dyopedos bispinis on the masts}

Among 1057 masts identified in underwater photos, 757 structures were inhabited (72\%) and sorted into the following groups (Table 1): (1) masts occupied by one or several juveniles (195 masts, 26\% inhabited); (2) masts occupied by a single adult (or subadult) female, often with several juveniles (402 masts, 53\%); (3) masts occupied by 1 adult or subadult male, rarely with juveniles (30 masts, 4\%); (4) masts occupied by two adults (female and male), often with juveniles (125 masts, 17\%); (5) masts occupied by three adults (5 masts, less than $1 \%$ ), typically two females and one male.

During dives, masts occupied by three or more (up to 23) adults were also observed (Table 2), and in one case, all 15 females inhabiting one mast were ovigerous. Such masts were rarely observed, but they were unusually long, measuring approximately $15-20 \mathrm{~cm}$, and were easily detected. Ordinary masts are typically not more than $10-12 \mathrm{~cm}$ in length.

\section{Substrata for mast building and formation of the basal section}

Dyopedos bispinis masts can be attached to solid substrata (stones, shells of dead or living molluscs and brachiopods) or to other fouling organisms including hydroids, bryozoans, ascidians and sponges; masts rarely occur on soft ground (sand and mud). Examination of the collected masts showed that the most frequent substrata are other organisms, particularly hydroids (Gonothyraea loveni (Allman, 1859), Ectopleura larynx (Ellis \& Solander, 1786), Eudendrium sp., Sertularia mirabilis (Verrill, 1873)), bryozoans (Eucratea loricata (Linnaeus, 1758), Flustra sp., and Scrupocellaria sp.), sponges (presumably Leucosolenia complicata (Montagu, 1814)) and, occasionally, amphipod tubes (Crassicorophium bonellii).

\begin{tabular}{llcc}
\hline N of group & Habitancy of mast & Number of masts & Proportion of masts \\
\hline 1 & 0 adults + juv & 195 & $26 \%$ \\
2 & 1 adult (f) + juv* & 402 & $53 \%$ \\
3 & 1 adult $(\mathrm{m})+$ juv* & 30 & $4 \%$ \\
4 & 2 adults $(\mathrm{f}+\mathrm{m})+$ juv* & 125 & $16 \%$ \\
5 & 3 adults $(2 \mathrm{f}+\mathrm{m}, \mathrm{f}+2 \mathrm{~m})+$ juv* & 5 & $<1 \%$ \\
\hline
\end{tabular}

\begin{tabular}{llll}
\hline Mast number & Adult Females & Adult Males & Juveniles \\
\hline N1 & 23 & 2 & 10 \\
N2 & 15 & 5 & 15 \\
N3 & 5 & 1 & 35 \\
N4 & 2 & 1 & 18 \\
N5 & 2 & 1 & 14 \\
\hline
\end{tabular}

Table 1. Habitancy of typical Dyopedos bispinis masts. Inhabited masts were divided into five groups according number of adult individuals on each mast, and the numbers and proportions of masts in each group are presented in the table columns. Abbreviations: $\mathrm{f}$ - adult female, juv - juvenile, $\mathrm{m}$ - adult male, $*$ - juveniles are occasionally present.

Table 2. Habitancy of collective Dyopedos bispinis masts. Amphipods inhabiting each mast (N1-N5) were divided into three groups: "adult females", "adult males" and "juveniles"; their numbers are presented in the table columns. 

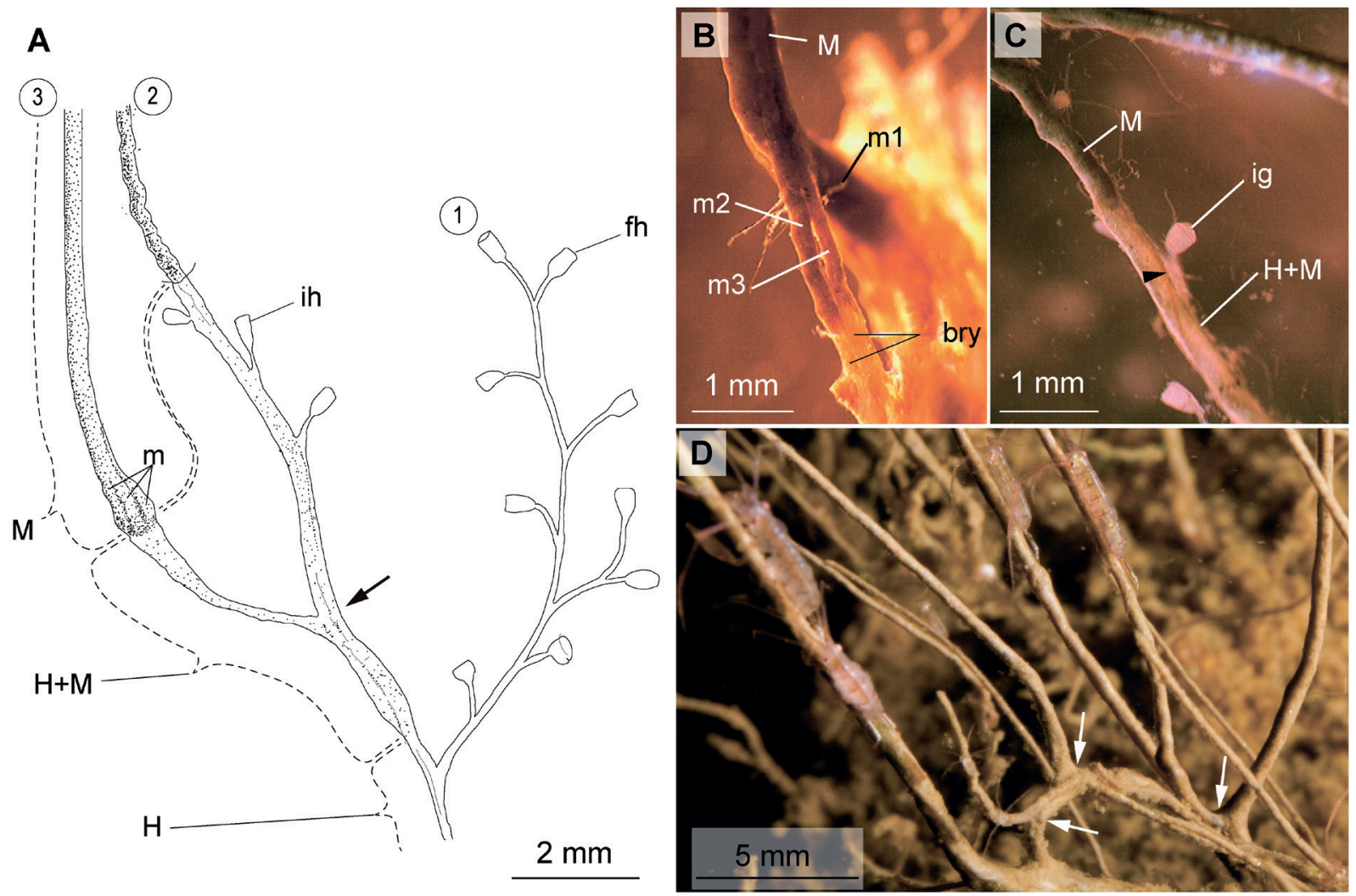

Fig. 2. Attachment of Dyopedos bispinis masts to hydroids and bryozoans, multi-supporting and branching masts. A - schematic drawing of two masts attached to a hydroid colony, showing that hydroid branches can be immured by Dyopedos bispinis to varying degrees; B and $\mathrm{C}$ - light microscopy (LM) photos showing mast attachment to bryozoans (B) and hydroids (C); D - underwater photo of a branching mast. Abbreviations: 1 - free hydroid branch; 2 - partially immured hydroid branch continuing as a single-supporting mast; 3 - completely immured hydroid branch continuing as a multi-supporting mast; arrows - branching sites of masts; arrowhead - filamentous algae included in mast cortex; fh - free hydranth; $\mathrm{H}$ - free section of hydroid branch; ih - partially immured hydranth; $\mathrm{m}, \mathrm{m} 1, \mathrm{~m} 2$ and $\mathrm{m} 3$ - basal masts forming multi-supporting mast; $\mathrm{M}$ - mast itself; $\mathrm{H}+\mathrm{M}$ - basal section of mast built around a hydroid branch; bry - bryozoan branches.

On solid substrates, the bases of the masts are disklike or weakly thickened, but on bush-like hydroid and bryozoan colonies, the masts are attached to the tips of branches (Fig. 2A-C). These masts typically coat a section of the colonies heading downward $(\mathrm{H}+\mathrm{M})$, often reaching the base, so that they appear to have been built directly on the solid substrate, without the hydroid or bryozoan.

When more than one mast attaches to a hydroid colony, a ramified mast occasionally results (arrows, Fig. 2A, D). Large masts typically have several supports; i.e., they are composed of several independent hydroid or bryozoan branches combined or even several smaller masts $(\mathrm{m}, \mathrm{m} 1, \mathrm{~m} 2, \mathrm{~m} 3)$ that are attached to different individual branches (Fig. 2A, B).

Some hydroids coated with mast remain alive, and their hydranths are free of masts and have tentacles
(Fig. 2A, C). Other branches are completely immured (3, Fig. 2A).

\section{Structure of masts}

\section{Mast forms}

Dyopedos bispinis structures are representative of the masts of typical dulichiids (Fig. 1A); they are usually $2-6 \mathrm{~cm}$ long and rarely reach $16-20 \mathrm{~cm}$. Except for the smallest, masts have variable diameters but reach a maximum at the base and a minimum nearer the tip. The diameter in the middle of the masts varies between 0.02 (smallest) and $0.1 \mathrm{~cm}$.

\section{Internal mast structure}

Masts comprise a relatively homogeneous central cylinder $(\mathrm{C}$, diameter 70-460 $\mu \mathrm{m})$ and a laminated cortex 

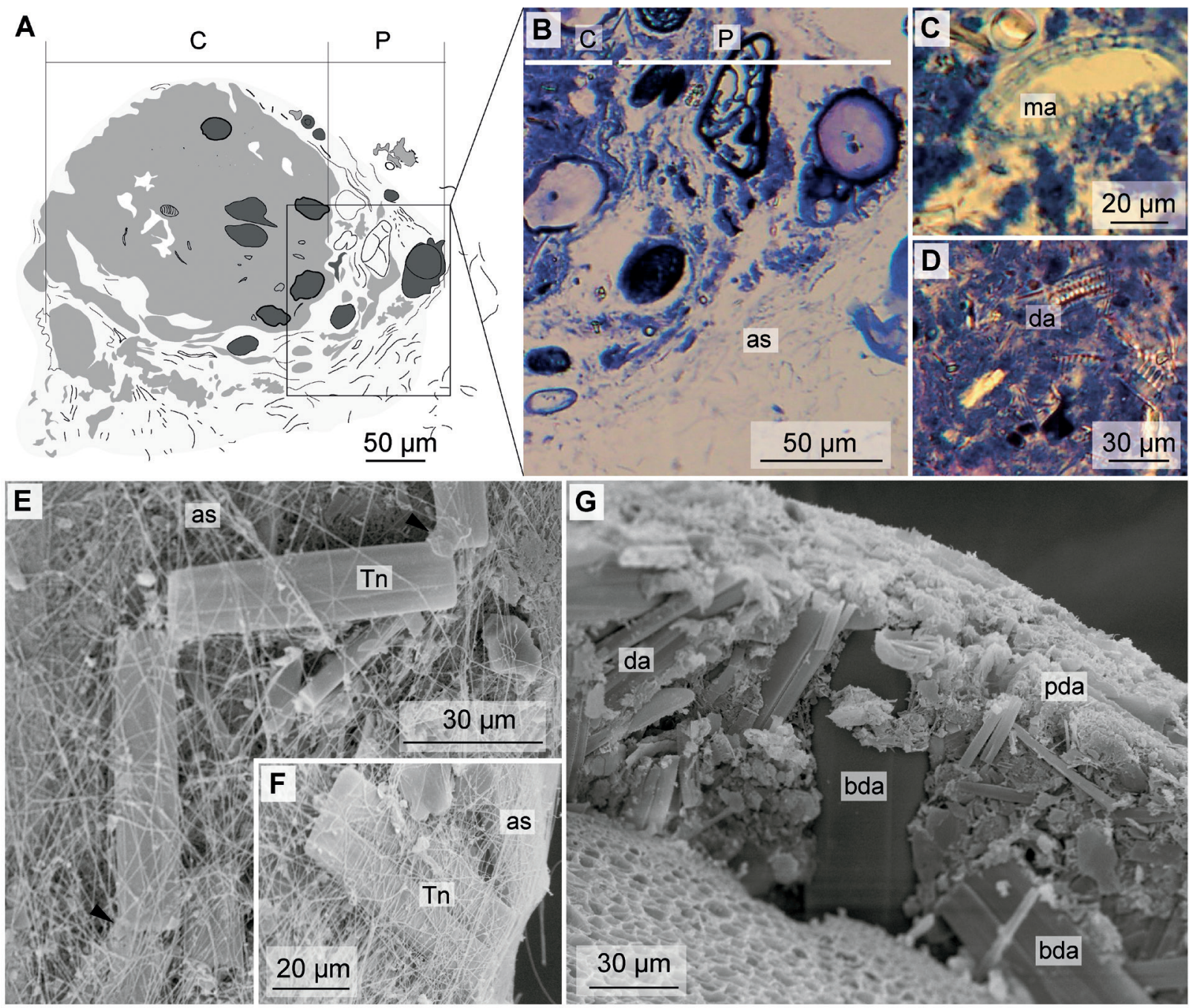

Fig. 3. Internal structure of a Dyopedos bispinis mast including diatoms and multicellular algae. A - drawing of a semi-thin mast crosssection; B - enlarged detail of A, LM micrograph; C and D - LM micrographs of semi-thin sections illustrating algae included in the central mast cylinder; E and F - SEM micrographs of mast surface showing the diatom Thalassionema nitzschioides; G - SEM micrograph of the inside of the mast laminated cortex showing the presence of numerous pelagic and benthic diatoms. Arrowheads - mucous pads connecting T. nitzschioides cells; as - silk threads; bda - likely benthic diatoms; C - central cylinder of the mast; da - diatoms; ma - multicellular algae; $\mathrm{P}$ - laminated cortex of the mast; pda - likely pelagic diatoms; $\mathrm{Tn}$ - diatom Thalassionema nitzschioides.

(P, from $440 \mu \mathrm{m}$ to $20 \mu \mathrm{m}$ thick and thinner), but the boundary between these structures is occasionally fuzzy (Fig. 1A-D and Fig. 3A). The size of the cortex varies greatly and might account for approximately 0 to $70 \%$ of the mast diameter. Along the mast length, the diameter of the cylinder varies only slightly (190-270 $\mu \mathrm{m})$, but the cortex gradually thins toward the tip of the mast (Fig. 1A-D).

The lower portion of the mast often contains several central cylinders (several smaller masts, C1-C4, Fig. 1A,
D), and one cylinder is typically thicker than the others $(\mathrm{C}-1 \mathrm{~m})$. Each cylinder is coated with its own cortex (P$1, \mathrm{P}-2)$, but together they share one common coat (P-c).

The central cylinder of the mast is composed of closely packed detritus; we did not detect any cementing mucus. The cortex of the masts contains amphipod silk (as) and detritus. A thin cortex (up to $20 \mu \mathrm{m}$ ) might be almost entirely composed of silk (Fig. 1A-B, Fig., $4 \mathrm{~A})$, but when the cortex is even slightly thicker, the proportion of detritus is much larger than that of silk 

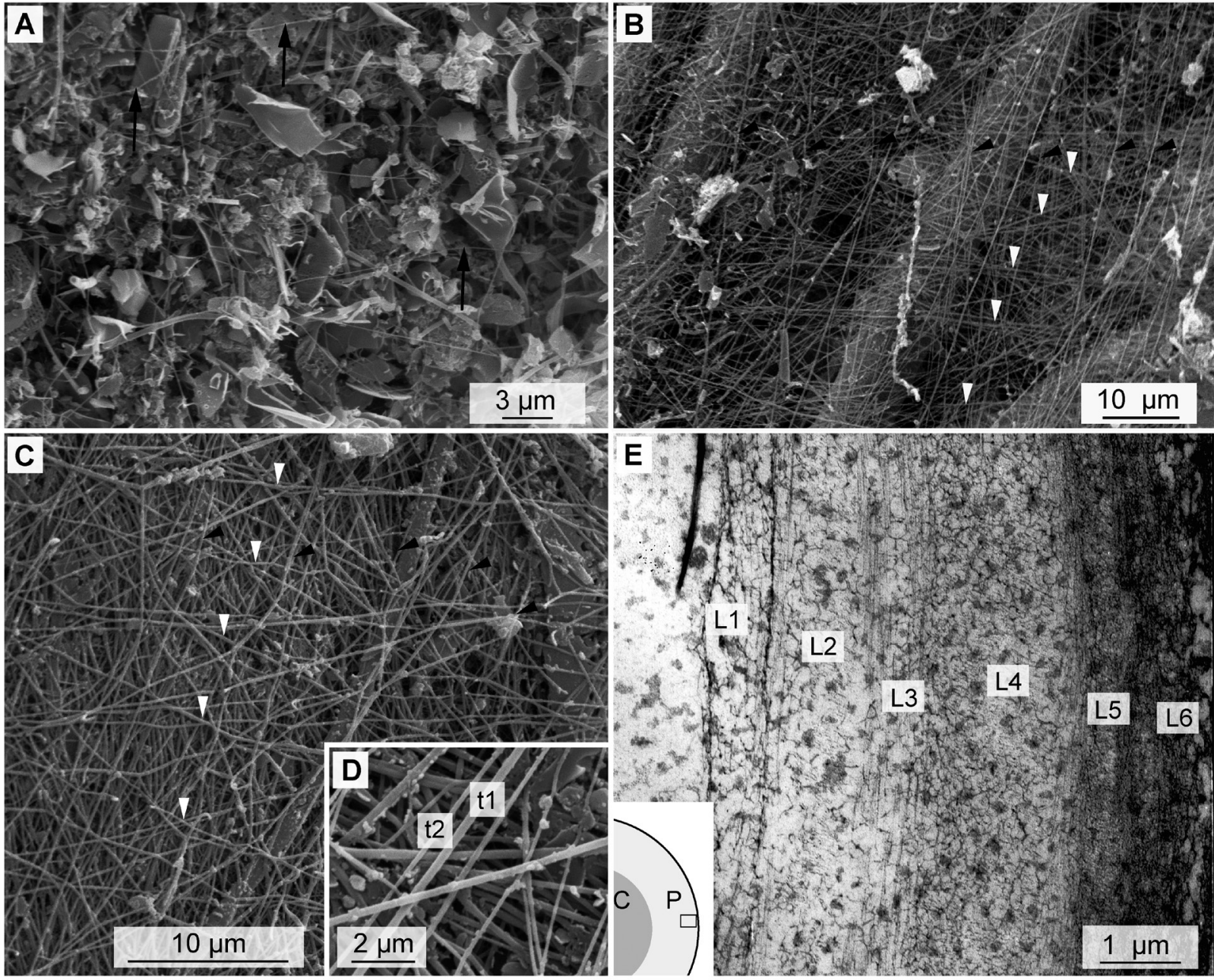

Fig. 4. Ultrastructure of Dyopedos bispinis mast surface. A, B, C and D - SEM micrographs of the mast surface near the distal tip (A) and other parts of the mast (B, C and D) showing that silk threads were thinner near the mast tip (arrows, A) than elsewhere (arrowheads, $\mathrm{B}$ and $\mathrm{C}$ ), that threads of varying widths are sometimes presented (t1 and t2, D), that detritus can be visible through the silk layer (B) or not (C) and that regular parallel silk threads are sometimes observable (black and white arrowheads, B and C); E - transmission electron microscopy (TEM) micrograph of an ultra-thin mast cross section showing numerous amphipod silk layers (L1-L6) on the mast surface. Abbreviations: arrows - thin threads; arrowheads - regular parallel thick silk threads; C - central cylinder in mast cross-section; L1-L6 - layers of silk threads (L1 and L3 - threads, likely lying perpendicular to the mast axis; other - at an angle); P - mast cortex in cross section; $\mathrm{t} 1$ and $\mathrm{t} 2$ - threads of varying widths.

(Fig. 1A, C, F). The detritus is represented by isolated or groups of particles surrounded by silk (Fig. 3A-B) or detritus layers (DL) alternating with silk layers (ASL, Fig. 1F). Under mechanical impact, the cortex of the dried mast exfoliates and becomes separate layers of approximately $5 \mu \mathrm{m}$ in thickness (Fig. 1E).

Numerous diatoms are present within masts (da, bda, pda, Tn, Fig. 3D-E). Some are pelagic (pda, Tn), and others are large and likely benthic species (bda). Diatoms have not been observed on the mast surface outside the silk layer.

\section{Fine mast structure}

The mast surface is covered with a layer of silk threads, and the thickness of the silk layer varies (Fig. 4A-C). The silk threads are oriented in all directions and are sometimes almost parallel to the mast axis. Frequently, regular shifts in the parallel threads (approximately 5 $\mu \mathrm{m})$ are observed (arrowheads, Fig. 4B-C). Furthermore, TEM photos suggest that the silk layer contains sublayers (L1-L6) that likely differ based on their angle of orientation (various directions or perpendicular to the mast axis), thickness and density (Fig. 4E). 
A

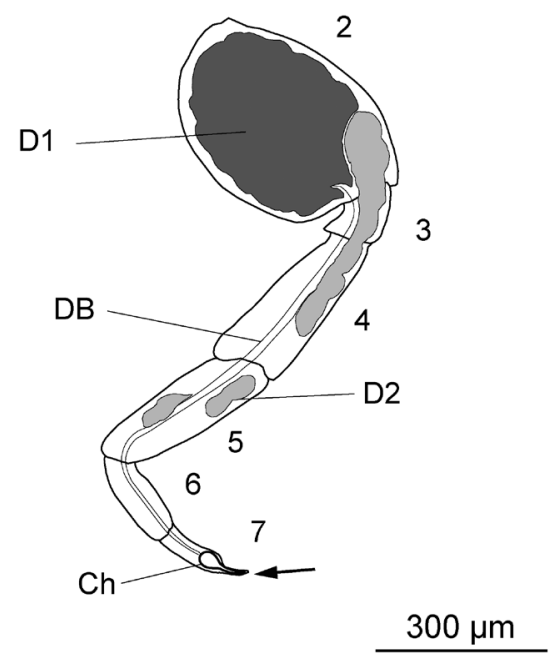

B

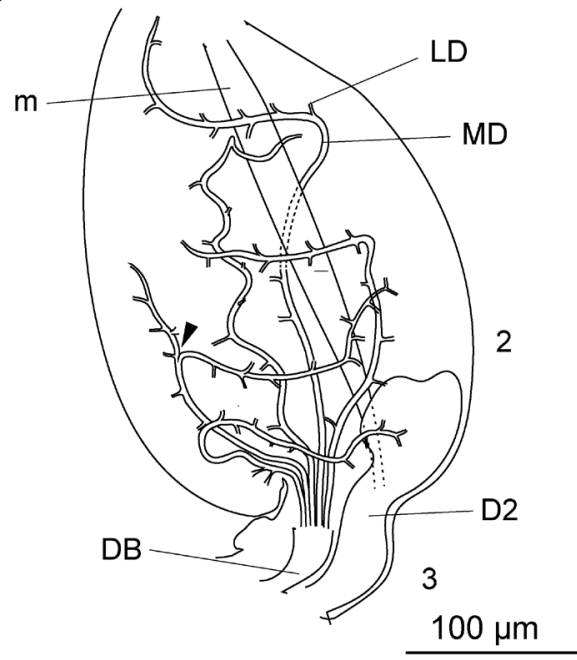

Fig. 5. Dyopedos bispinis pereopodal silk-producing glands, schematic reconstructions from serial sagittal, semi-thin sections. A - Distribution of glands in female Dyopedos bispinis 3-d or 4-th pereopod, showing two gland groups, proximal (D1) and distal (D2), and their ducts falling into a common chamber in the tip of the leg; B - duct system of the D1 glands in the basis of pereopods 3 or 4, female. Abbreviations: arrow - common opening of all pereopodal glands; arrowhead - point of coalescence of two D1 main ducts; Ch - dactylar chamber; D1 - proximal glands (D1); D2 - distal glands (D2); DB - duct bundle; LD - lateral duct of D1 gland; m - pereopodal muscles; MD - main duct of D1 gland. Arabic numerals - number of pereopod segments; 2 - basis; 3 - ischium; 4 - merus; 5 - carpus; 6 - propodus; 7 - dactylus.

Silk threads are 0.1-0.3 $\mu \mathrm{m}$ in diameter, and threads of varying widths $(\mathrm{t} 1, \mathrm{t} 2)$ might be observed on the same mast (Fig. 4D). However, we did not observe threads with changing diameters in the photos. The surfaces of the analysed mast tips were covered with thinner threads $(0.1 \mu \mathrm{m})$ (arrows, Fig. 4A), whereas the remainder of the mast was coated with $0.3-\mu \mathrm{m}$ threads (arrowheads, Fig. 4B-C).

\section{Silk gland morphology}

\section{Silk gland general morphology (Fig. 5A)}

Silk glands have been detected in pereopods 3-4 of adult females, males and juveniles (including the youngest ones), and the secretory units (D1, D2) are situated in pereopod segments 2-5 (basis to carpus). The ducts are grouped into a single bundle (DB) leading to the dactylus (segment 7), where this bundle connect to a common chamber $(\mathrm{Ch})$ opening at the dactylus tip (arrow, Fig. 5A). The ducts are lined with epicuticle (2, Fig. 6E, G, I), whereas the chamber has a normal cuticle comprising endo-, exo- and epiuticle.

There are two distinct gland groups in each pereopod 3 or 4: proximal (D1) and distal (D2) (Fig. 5A). The D1 secretory granules stain more intensively with the mix of toluidine and methylene blue and are electron- dense (sg, Fig. 6,7) compared with the D2 granules (sg, Fig. 8).

Each female pereopod contains approximately 70 secretory cells.

\section{Proximal glands (D1) (Fig. 6, 7) \\ D1 gland location}

Female D1 secretory units are only located in the pereopod basis (segment 2), and in males, these structures were also found in the merus (segment 4). The D1 secretory ducts lead to the dactylus (segment 7) (Fig. 5A).

\section{D1 gland structural plan}

D1 secretory units comprise approximately 60 secretory cells (SC) lying along 5-6 main ducts (MD, Fig. 5B, Fig. 6A-C), and short (5-8 $\mu \mathrm{m}$ ) lateral canals (LD) individually branch away from the main duct to each secretory cell (Fig. 6A-C, E). Each lateral duct terminates into an intracellular globular accumulation site (as) that is 7-9 $\mu \mathrm{m}$ in diameter (Fig. 6A-C, E) and contains numerous cavities. TEM revealed that the accumulation site is composed of ramifying ductules (d) radiating from the end of the lateral duct (Fig. 6E, G-H).

Secretory cells do not contact the haemocoel and are covered with a lining (LC) composed of a strongly flattened cellular layer (Fig. 6E, J and Fig. 7). 

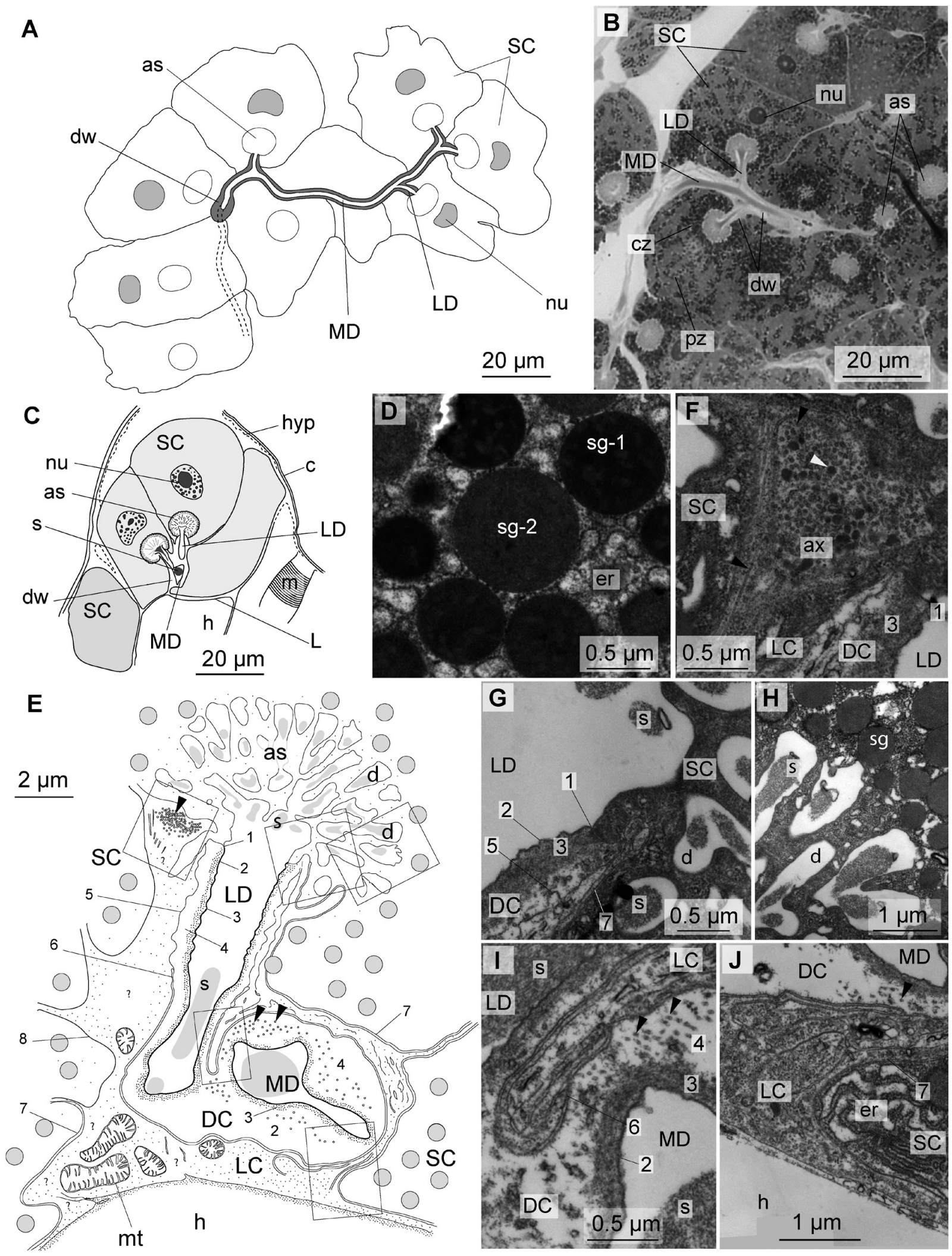


\section{Dl gland duct structure}

Ductules within the accumulation site are situated directly in the secretory cell, and the lumens are separated from the cytoplasm by a thin (approximately $0.001 \mu \mathrm{m}$ ) electron-dense layer (Fig. 6E, G-H). It is not clear whether this layer comprises only membrane or if it also contains epicuticle; microvilli are lacking.

The main and lateral ducts are surrounded by a nonstaining sheath (duct wall, dw), which has a variable thickness of up to $3 \mu \mathrm{m}$ (Fig. 6A-C). TEM (Fig 6E, G, $\mathrm{I}-\mathrm{J})$ revealed that the duct wall of each D1 gland comprises two cells: "internal" and "external". The internal cell (which is really a duct cell, DC, Fig. 6E) contacts the duct lumen and the external cell and adjoins the secretory cell near the distal end of the lateral duct. The "external cell" (lining cell, LC) completely covers the "internal cell" and contacts secretory cells and the haemocoel; it is included in the gland lining (Fig. 6E, J). The cytoplasm of the duct ("internal") and lining ("external") cell is separated by two membranes (6, Fig. $6 \mathrm{E}, \mathrm{I})$, but the longitudinal sections of the lateral duct showed only one membrane between these structures (5, Fig. 6E, G). Thus, the structures what we call "duct" and "lining cells" are possibly components of a single complicated cell.

Duct cells (inner part of the duct wall) comprise the next layers (Fig. 6E, I): (1) the innermost thin electrondense $(0.0015-0.003 \mu \mathrm{m})$ layer, which likely includes the membrane and epicuticle; (2) a grainy electrondense layer $(0.1-0.3 \mu \mathrm{m})$, likely comprising actin filaments; (3) a wide electron-lucent layer (3-4 $\mu \mathrm{m})$ containing microtubules, parallel to the duct axis, and occasionally with membrane structures; and (4) an outer cellular membrane. These layers are continuous and closed, and the radial connection between the inner and outer cellular membranes (mesaxon) is absent. The cell cytoplasm contains microtubules and different membrane structures (Fig. 6E, I, J).

The intracellular location of the main ducts remains in the subsequent appendage segments.

Secretory product was observed in the lumens of the intracellular ductules, lateral and main ducts (s, Fig. $6 \mathrm{~B}-\mathrm{C}, \mathrm{E}, \mathrm{G}-\mathrm{I})$. In each lumen, this product is aggregated into compact bodies, and its electron density and structure are similar to those of the secretory granules in secretory cells (sg, Fig. 6D, H and Fig. 7C-D).

\section{D1 secretory cell structure}

Secretory cells (Fig. 6A-C) vary in form and size (cell diameter of 5-35 $\mu \mathrm{m}$ ) and are mononuclear. The semilunar nucleus (nu) is located near the centre of the cell, opposite the lateral duct (Fig. 6A-C). Secretory cells contain numerous secretory granules (sg, Fig. 6B, E, H) situated densely in the area adjacent to the accumulation site (cz) and more sparsely at the periphery (pz, Fig. 6B). Mitochondria (mt) and granular endoplasmic reticulum (er) are situated in the spaces between the granules (Fig. 6D, J and Fig. 7C).

Secretory granules (sg, Fig. 6B, D, H, and Fig. 7C) have permanent circular forms (approximately 0.6-1.0 $\mu \mathrm{m}$ in diameter) and stain intensely with a mix of toluidine and methylene blue. The granular material in the thin sections is electron dense and can be heterogeneous to varying degrees (sg-1, sg-2 in Fig. 6D, and sg in Fig. 7C).

The secretory cell membrane forms invaginations (i) filled with extensions of lining cell cytoplasm (Fig. 7A-D), and these invaginations can be significantly deep, reaching the accumulation site. The invaginations are narrow $(0.05-0.15 \mu \mathrm{m})$ but widen at some sites (Fig. 7C, D), particularly at the end/tip of the invagination (Fig. 7D). Additionally, the invaginations occasionally branch (Fig. 7B). The pattern of invagination distribution was observed in two consecutive serial sections

Fig. 6. Structure of Dyopedos bispinis proximal pereopodal glands (D1). A - 2D schematic reconstruction of D1 gland fragment from serial longitudinal semi-thin sections; B - fragment of D1 gland, longitudinal semi-thin section, LM micrograph; C - D1 gland, semithin cross section; D - fragment of secretory cell cytoplasm (TEM photo) showing secretory granules; E - D1 gland, schematic drawing of ultra-thin cross section; F, G, H, I and J - enlarged details indicated in E (TEM photo) showing axon terminal adjacent to secretory cell $(\mathrm{F})$; boundaries between secretory, duct and lining cells $(\mathrm{G})$; fragment of accumulation site $(\mathrm{H})$; fine structure of main and lateral ducts (I); and differences in ultrastructure of secretory, lining and duct cells (J). Abbreviations: black arrowheads - microtubules in duct and nerve cells; white arrowheads - vesicles in nervous cell; as - accumulation site; c - surface cuticle of pereopod; cz - central area of secretory cell with abundant secretory granules; d - ductules in secretory cell; dw - duct wall, including duct cell and lining; er - endoplasmic reticulum; $\mathrm{h}$ - haemocoel; hyp - hypoderm; LD - lateral duct; $\mathrm{m}$ - pereopod muscles; $\mathrm{MD}$ - main duct; mt - mitochondria; nu - nucleus of secretory cell; pz - peripheral area of secretory cell cytoplasm with rare secretory granules; s - secretion in duct lumen; SC - secretory cell; sg - secretory granules in secretory cells; sg-1, sg-2 - secretory granules, differing in electrone dense; ? - fragments of glandular tissue damaged during fixation. Arabic numerals - details of duct wall; 1 - boundary between secretory and duct cells; 2 epicuticle lining the main and lateral ducts; 3 - grainy electron-dense layer of duct cell; 4 - electron-lucent layer of duct cell; 5 and 6 boundary between duct and secretory cells, comprising one (5) or two (6) membranes, respectively; 7 - boundary between secretory and lining cells; 8 - boundary between lining and duct cells damaged during fixation. 

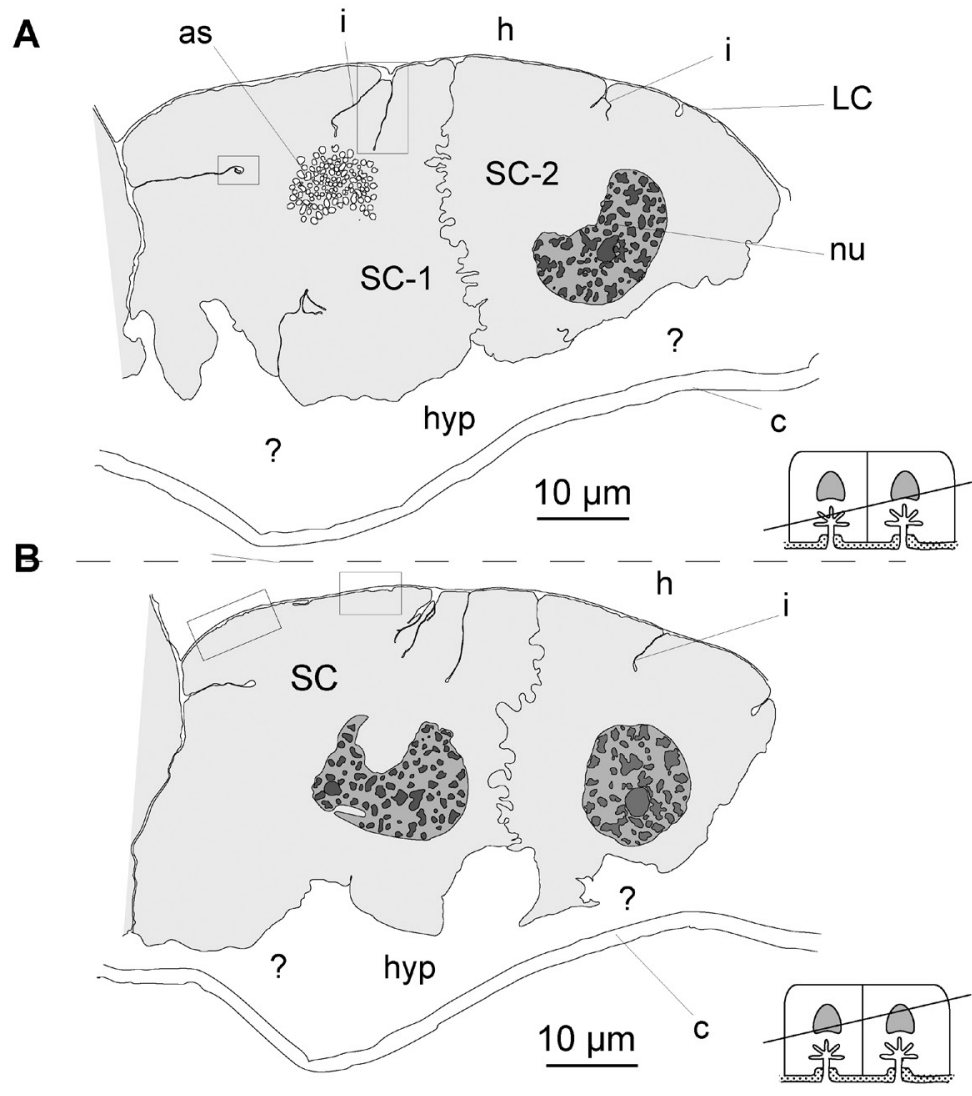

E

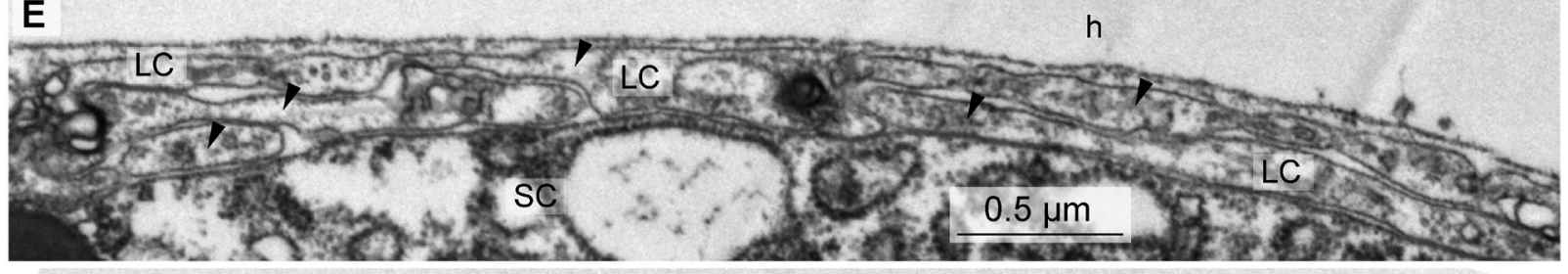

$\mathbf{F}$

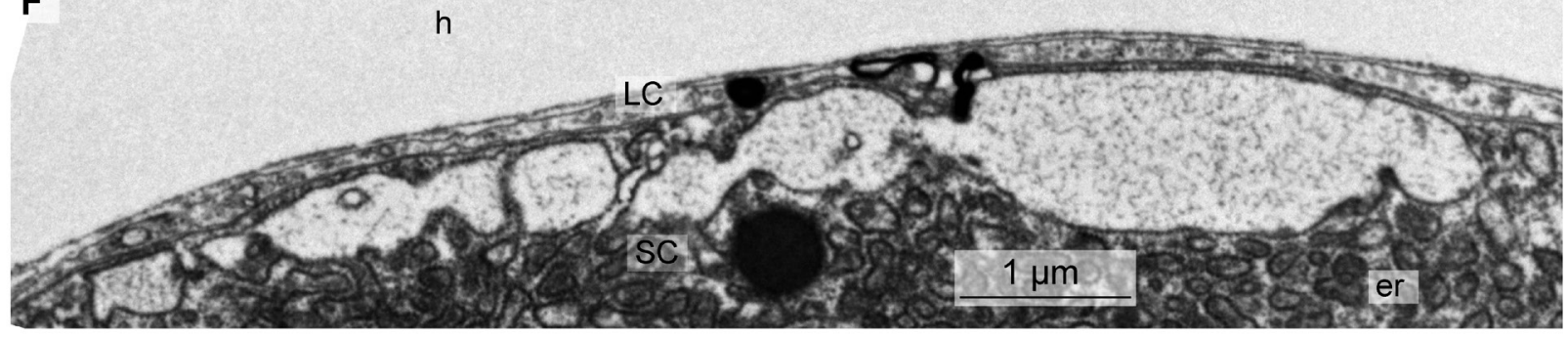

Fig. 7. Cellular membrane invaginations in D1 secretory cells. A and B - schematic representations of two consecutive serial ultra-thin sections (with a 3-5- $\mu \mathrm{m}$ interval) through the D1 gland, showing that the invaginations (i) are likely flat and perpendicular to the section plane; C - TEM micrograph illustrating deep secretory cell invaginations filled with lining cell extensions; D - TEM micrograph of the widening at the tip of an invagination; $\mathrm{E}$ and $\mathrm{F}$ - TEM micrographs showing different forms of lining represented as multiple overlapping cytoplasmic extensions (E) or as a continuous cytoplasmic layer $(\mathrm{F})$. Abbreviations: arrowheads - overlapping lining cytoplasmic extensions; as - accumulation site; c - cuticle; er - endoplasmic reticulum; $\mathrm{h}$ - haemocoel; hyp - hypoderm; i - cellular membrane invaginations of secretory cells; LC - lining cell; mt - mitochondria; nu - nucelus of secretory cell; SC, SC-1 and SC-2 - secretory cells; sg secretory granules; ? - fragments of tissue damaged during fixation or embedding. 

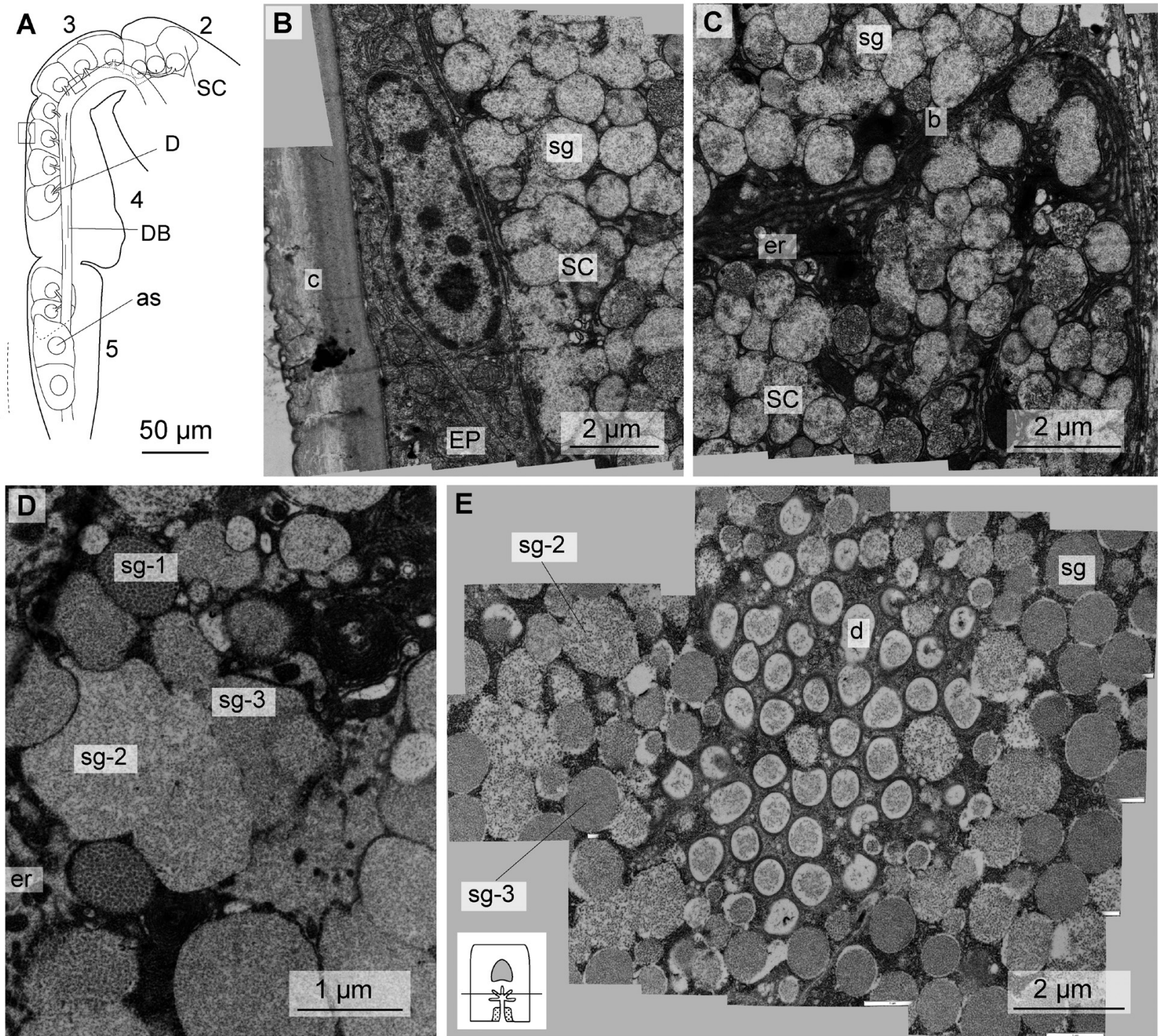

Fig. 8. Structure of distal pereopodal glands of Dyopedos bispinis (D2). A - reconstruction drawings from semi-thin serial sections; B - D - TEM micrographs. A - D2 gland distribution; B - periphery of D2 secretory cell directly adjoining the hypoderm; C - periphery of two D2 secretory cells and the boundary between them; D - different types of secretory granules in D2 cell cytoplasm; E - accumulation site of D2 secretory cell. Abbreviations: as - accumulation site; b - boundary between two D2 secretory cells; c - cuticle; D - duct; $d$ - ductules forming the accumulation site; DB - bundle of D1 and D2 gland ducts; er - endoplasmic reticulum; SC - secretory cell; sg, sg-1, sg-2 and sg-3 - different types of secretory granules. Arabic numerals - number of pereopod segments; 2 - basis; 3 - ischium; 4 - merus; 5 - carpus.

(with a 3-5 $\mu \mathrm{m}$ interval) perpendicular to the lateral duct planes (Fig. 7A-B). Therefore, we propose that these invaginations have a flattened form and are located in the plane of the lateral duct.

\section{Dl lining structure}

The lining cells (LC), located between the secretory cells and the haemocoel (h) (Fig. 6C, E, J, and Fig. 7), are strongly flattened (approximately $0.2-0.4 \mu \mathrm{m}$ in thickness) but expand to surround the gland ducts (Fig. $6 \mathrm{C}, \mathrm{E})$ or to hold the nucleus or mitochondria. These cells form extensions into (see above) and between the secretory cells.

In some sections, the lining appears as a continuous cytoplasmic layer (Fig. 7F), while in other sections, the lining comprises multiple overlapping cytoplasmic extensions (arrowheads, Fig. 7E). The lining cytoplasm 
contains microtubule bundles, membrane vesicles or elongate structures (Fig. 7C, E-F). Near the accumulation site between the secretory and duct cells, we detected a structure (Fig. 6F) containing numerous microtubules (black arrowheads) and electron-dense round structures $0.006-0.1 \mu \mathrm{m}$ in diameter (white arrowheads) that is likely axon terminal.

\section{Distal glands (D2) (Fig. 8)}

\section{D2 gland location}

The D2 secretory cells in adult females are located in the 2-5 appendage segments (basis-carpus) (Fig. 5A, and Fig. 8A) in three distinct cell groups along the bundle of D1 and D2 ducts. The largest group contains 1011 cells and begins in the basis (segment 2 ) and ends at the merus (segment 4). Two other groups, comprising 1-3 cells, are situated in the carpus (segment 5) (Fig. 5A and Fig. 8A).

\section{D2 glands structure}

Inside each D2 secretory cell, there is an accumulation site (as) with a duct (D, resembling a D1 gland lateral duct) leading away (Fig. 8A). This duct is lost in the duct bundle (DB), and it is unclear whether it falls into any other ducts or remains separate. The accumulation site, as in the D1 glands, comprises numerous radiating ductules (d, Fig. 8E). The gland duct has a separate wall, likely containing a duct cell cytoplasm, but the wall ultrastructure has not been investigated.

The secretory cells (SC) are 25-35 $\mu \mathrm{m}$ in size, uninuclear, and filled with secretory granules (sg), and in the cell periphery, the granules are situated less densely than near the accumulation site. The space between the granules was observed to be heterogeneous, suggesting that this space is filled with poorly preserved endoplasmic reticulum (er, Fig. 8C-D). Secretory granules are occasionally round, but when densely situated, the shape changes (Fig. 8D). These cells lightly stain with toluidine blue and contain loose electron-lucent material. Within one cell, the secretory granules vary in their electron density and the regularity in which the material is arranged (sg1-3, Fig. 8D). We did not observe any regularity in the different granules distributed throughout the cell. Cell membrane invaginations were not observed in D2 secretory cells.

\section{Discussion}

Social behaviour and mast-building in Dyopedos bispinis

\section{Social structure on masts}

Dyopedos bispinis masts are typically inhabited by no more than one adult female and no more than one adult male, indicating that the territorial behaviour of $D y$ opedos bispinis is similar to that of other Dyopedos species (Mattson and Cedhagen, 1989; Thiel, 1997). Each large mast of Dyopedos monacantha or Dyopedos porrectus is a territory belonging to a single adult female. Only one male can enter, and female descendants can remain for some time on the maternal mast.

Adult male Dyopedos bispinis are occasionally observed on individual masts, but it is unknown whether these males, such as those of Dyopedos porrectus (Mattson and Cedhagen, 1989), can construct their own masts or whether, similar to male Dyopedos monacantha, they use abandoned masts, which are numerous in sea bottom landscapes.

Extended maternal care has been reported in some dulichiid species (McCloskey, 1970; Mattson and Cedhagen, 1989; Thiel 1997). Apparently, Dyopedos bispinis is no exception as numerous juveniles have been observed together with adult females on large masts.

\section{Collective masts}

In addition to the masts of Dyopedos bispinis being typical of species from the genus Dyopedos, in that they are usually inhabited by a single female, masts with two and more adult, and sometimes even ovigerous, females were observed. Mattson and Cedhagen (1989) reported Dyopedos monacantha masts with one large male and two smaller females (although not two large females), and McCloskey (1970) also observed masts with three nonbreeding adult Dulichia rhabdoplastis. However, among other building corophiids, the coexistence of several adult females in one dwelling is unknown (Thiel, 2007; Moore and Eastman, 2015). However, some leucothoid amphipods (Thiel, 2000) and other symbiotic malacostraca (Duffy 2002, 2007) have been described inhabiting the inner canals of sponges. The corophiid tube has only one or two openings for outside feeding and only a single place for intratubular filtration (Dixon and Moore, 1997). In contrast, if the mast is long enough, then multiple individuals could probably feed without hindering each other because Dyopedos spp. utilize the water current perpendicular to the mast axis for feeding (Mattson and 
Cedhagen, 1989). However, it is not clear why collective Dyopedos masts are not widespread. Some possible explanations include mechanical factors (current, waves, substrate quality) or fish-predation pressure, as reported for Dyopedos monacantha, (Mattson and Cedhagen, 1989) which could, in theory, increase with mast elongation.

It is also unknown whether the adult amphipods inhabiting one mast are relatives (is it a parent-offspring or conspecific association? See Thiel, 2011) and whether these crustaceans defend the mast from interspecific competitors. Most likely, these congested masts reflect the development of extended parental care, which has been described in Dyopedos spp. (Mattson and Cedhagen, 1989; Thiel, 1997). However, increasing levels of interspecific aggression typically force juveniles to leave the maternal mast (Mattson and Cedhagen, 1989), and the number of juveniles on the mast rapidly declines with growth (Thiel, 1997). It is possible that a certain aggression suppression mechanism could be involved that would allow the brood to remain on the mast. It is also unknown whether the mother of the brood remains on the mast and, consequently, whether adult amphipods from different generations can coexist on the mast. Parent-offspring groups, iteroparity and the coexistence of several offspring cohorts were observed in many percarids (Thiel, 2007), but overlapping generations (offspring that begin to reproduce in the presence of reproductive parents) and coexisting reproducing adult offspring in the maternal dwelling has not been reported (Thiel, 2007; Thiel, 2011). Although much remains to be discovered, Dyopedos bispinis exhibits the movement from a typical corophiid small parent-offspring group to more complex groups with different social structures.

\section{Cooperative mast building}

"Collective" masts are typically much longer than individual masts, likely reflecting cooperative mast maintenance. Indeed, all adults have pereopod glands, so it is difficult to identify a single builder. However, "individual" masts might also be considered a product of cooperative building; for example, Dyopedos monacantha males share the maintenance of female masts, using pereopods 3-4 (Mattson and Cedhagen, 1989). Dyopedos bispinis males have developed pereopod glands, and it is quite likely that they also use these structures. Moreover, these glands are developed in the youngest Dyopedos bispinis juveniles. Silk threads of different diameters are found on the mast surface, which could also be viewed as a result of cooperative building (for more detail, see Discussion section 4.1. on "nonpereopodal secretions"). Juveniles of Dyopedos monacantha leave the maternal mast to build their own masts at different ages (Thiel, 1997), suggesting that there is a time period in which young amphipods are capable of building but inhabit the maternal mast. Thus, although we do not have direct evidence that juveniles participate in maternal mast maintenance, we suggest that, in some cases, juveniles begin to strengthen (build up) and elongate the maternal mast instead of leaving it, leading to the appearance of collective masts.

Ecological aspects of mast-building in Dyopedos bispinis

\section{Habitats of Dyopedos bispinis}

Dyopedos bispinis is abundant in conditions with strong currents; their masts are rarely observed on mud but are often on hydroids. Thus, Dyopedos bispinis habitats are more similar to those of Dyopedos porrectus than Dyopedos monacanthus (Moore and Earll, 1985; Mattson and Cedhagen, 1989). Although Dyopedos porrectus was also detected in Velikaya Salma Strait, it was absent in the biotopes studied in this paper; thus, further investigations are required.

\section{Mast-building and foreign organisms}

The masts of different dulichiids were observed on hydroids (Dyopedos porrectus, Moore and Earll, 1985), sea urchin spines (Dulichia rhabdoplastis, McCloskey, 1970), shells, polychaete tubes (Dyopedos monacantha, Mattson and Cedhagen, 1989), and amphipod tubes (Dulichia falcata (Bate, 1857), Kanneworff and Nicolaisen, 1972). Dyopedos porrectus has also been associated with bryozoans (Lincoln, 1979, cit. ex. Moore and Earll, 1985). Dyopedos bispinis, although not observed on sea urchins, uses a wide range of organisms as substrata including hydroids, bryozoans, sponges, molluscs, brachiopods and Crassicorophium tubes. Importantly, mast building on hydroids can be easily underestimated because the hydroid can be fully disguised as a part of the mast. Hydroids and bryozoans often occur immured, and it is likely that the building activity of Dyopedos bispinis negatively affects substratum organisms. Because Dyopedos bispinis is a dominant species in the Velikaya Salma Strait (Zhadan et al., 2007), the influence of masts on the benthic ecosystem might be significant.

McCloskey (1970) reported that numerous diatoms cover the surfaces of the masts of Dulichia rhaboplas$t i s$, but diatoms are usually only sparsely present on 
masts of other Dulichiidae (Moore and Earll, 1985; Mattson and Cedhagen, 1989). Additionally, Dyopedos bispinis masts do not have abundant diatom epiflora. Nevertheless, diatoms are abundant in the detritus used to form masts (Fig. 3D-G), and some of pelagic forms likely remain alive for some time because they have mucous pads (arrowheads, Fig. 3E). It is not known whether this is a frequent occurrence or how long these forms survive, but these "former pelagic" algae likely require further attention in the descriptions of community structure.

\section{Mast structure}

\section{Mast form}

Mast building by Dyopedos bispinis on hydroids occasionally leads to the appearance of branching masts (Fig. 2D), and this phenomenon is unknown in other dulichiids. Dyopedos bispinis are apparently territorial, and it remains unknown how these organisms share areas of conflict on the branching masts. Masts with several supports (Fig. 2A-B) have also not been previously described, and whether each individual builds additional masts or utilizes abandoned masts remains unknown.

\section{Internal structure and growth of the masts}

The mast of Dyopedos bispinis comprises a homogeneous central cylinder and a laminated cortex (Fig. 1A-D and Fig. 3A-B), and the mast surface is covered with a silk sheath (Fig. 1F and Fig. 4), confirming the observation of Mattson and Cedhagen (1989), who reported that mast construction begins with the formation of the detrital central region and continues through the production of silk layers. However, in addition to silk, the laminated cortex includes a large amount of detritus (Fig. 1C-D and Fig. 3A-B), and it is likely that detritus layers alternate with silk layers (Fig. 1F). Moreover, the thickness of the cortex is occasionally comparable to the radius of the central cylinder (Fig. 1C-D).

Thus, we propose that there are different methods for developing the mast for different purposes: (A) mast reinforcement with only silk threads (described by Mattson and Cedhagen (1989)) and (B) mast thickening with detritus and silk. It remains unknown whether thickening is realized by active amphipod activities or by passive detritus settlement and gluing.

Detritus for mast building and maintenance can likely be collected from both the water column and from the bottom because both planktonic and benthic diatoms are present in the mast (bda, pda, Tn in Fig.
3E-G). Both methods were described for Dyopedos monacantha (Mattson and Cedhagen, 1989).

Mast thickening is likely necessary as mast size increases with amphipod growth. The design of the mast facilitates growth without structural disturbance. In contrast, tube-building amphipods, according to the observed data, occasionally (a) leave old dwellings and build new, more spacious tubes, (b) stretch existing tubes, and (c) break old tubes into pieces and build new tubes utilizing these pieces during body growth (Goodhart, 1939; Barnard et al., 1988). Thus, gradual build up is at least occasionally not an option for tube-building amphipods, unlike mast builders.

\section{Mast surface}

The surface of a Dyopedos bispinis mast is covered with silk threads that are oriented in various directions and in many layers (Fig. 3E, and Fig. 4A-D). For Dyopedos monacantha, it was observed that under conditions with strong currents, the silk threads are placed at different angles to increase mechanical strength. We collected Dyopedos bispinis masts from straits with strong tidal currents, and there was no prevailing silk direction in these conditions.

When covering the mast with silk, each Dyopedos monacantha pereopod 3-4 tip moves back and forth "along an ample half of the circumference of the mast" (Mattson and Cedhagen, 1989), and this spinning procedure gradually proceeds along the mast (Mattson and Cedhagen, 1989). In Dyopedos bispinis, regular parallel thread deposition was sometimes observed, and remarkably, a nearly rectangular, meshy structure was occasionally observed (Fig. 4B-C). A similar structure was identified by Moore and Earll (1985) in SEM photos of Dyopedos porrectus masts, and according to these authors, "the resultant meshwork is reminiscent of geodetic construction of aircraft fuselages and would confer relative strength together with flexibility". Similar silk structures were also observed in tube-building species, such as Crassicorophium bonellii and Peramphithoe femorata (Cerda et al., 2010; Kronenberger et al., 2012a).

\section{Silk and mucus production in tube- and mast-building species}

\section{Nonpereopodal secretions}

The amphipod silk produced by pereopods 3-4 is a very important component of tubes and masts. However, in some cases, additional secretions produced by other appendages are exploited for mast or tube building (Matt- 
son and Cedhagen, 1989; Goodhart, 1939), and these secretions are likely presented as glues. Their importance may be underestimated, especially as mouthparts and gnathopods are very often involved in material collection (Skutch, 1926; Meadows and Reid, 1966; Dixon and Moore, 1997). However, at least in Crassicorophium bonellii and Lembos websteri, the pereopodal silk also includes a mucopolysaccharide adhesive component (Kronenberger et al, 2012a,b). It remains unclear how widespread is the use of additional secretions among tube- and mast-building corophiids.

The tip of one of the examined masts was covered with threads (Fig. 4A) that were thinner than those in the remaining mast surface (Fig. 4B-C). They could be considered mucus threads, but according Mattson and Cedhagen, 1989, the mucus threads of Dyopedos monacantha are more than 10 times thicker than silk threads, and the mouthpart origin of the thin threads is doubtful. Because pereopods 3 and 4 are practically identical and likely to produce threads with similar diameters, we can offer two hypothesizes: threads of different diameters reflect (A) changes in thread diameter (for example, depending on the tension) or (B) shared building activity between several amphipods of different size. We did not detect threads with changing diameters, which supports the second hypothesis.

The mast SEM photos (Fig. 3E-G, and Fig. 4A-D) showed various detritus and silk threads, but we did not observe anything that could be accurately interpreted as cement or glue (amorphous mucus). We proposed that the mucus quantity is not great or that it is washed out during experimental fixation and treatment procedures. However, the fixed masts maintained such characteristics as form and flexibility. Therefore, one possibility is that mucus is important during the first stages of mast building, but silk threads subsequently provide the strength.

\section{Pereopod glandular complex composition}

Compositions of the pereopod 3-4 glandular complex are similar in Dyopedos bispinis and tube-building species. All studied corophiid species have two gland groups, proximal and distal, a common cuticular chamber and a single excretory opening (Nebeski, 1880; Kronenberger et al; 2012b; Neretin, 2016, and Fig. 5A). Dyopedos bispinis proximal glands (D1) are multicellular and have a strongly elongated form (i.e., "pseudotubular" glands, see discussion below in sections 5.45.6 and Fig. 9D-H), as has been observed in most other corophiid species (Nebeski, 1880; Neretin, 2016), likely with the exception of Crassicorophium bonellii and
Lembos websteri (Kronenberger et al., 2012b). It is not clear whether the distal glands (D2) or Dyopedos bispinis are multicellular like the proximal glands (D1) or whether each D2 secretory cell has an individual duct. Both variants have been identified in other amphipods: multicellular distal glands in Ampithoe spp. (Nebeski, 1880; Neretin, 2016) and glands including a single secretory cell in J. falcata (Nebeski, 1880).

According to Kronenberger et al. (2012b), the Crassicorophium bonellii and Lembos websteri glandular complexes comprise both rosette (as in Fig. 9C) and lobed glands. According to our findings, Dyopedos bispinis and Ampithoe rubricata glands are not typical rosette or lobed but have some common features with both these gland types (facultative binuclearity, presence of deep cell membrane invaginations and cellular composition, see discussion section 5 and Fig. 9). Considering that another species of Crassicorophium (Crassicorophium crassicorne) has elongated glands typical of other amphipods (Nebeski, 1880), these differences most likely reflect differences in terminology. On the other hand, the schematics by Kronenberger et al., (2012b) show typical rosette glands. Thus, it remains in question whether the structure of the pereopodal glands of Crassicorophium bonellii and Lembos websteri is unique among other corophiids.

\section{Volume of pereopodal glandular complex}

Although the Dyopedos bispinis masts are large structures compared with the length of the amphipod body, we have not observed Dyopedos bispinis glands to be strongly enlarged compared with tube-building species. The number of secretory cells (approximately 70 in each Dyopedos bispinis pereopod, Fig. 5B, 8A) is lower than in other species (about 130 in Crassicorophium bonellii, based on figures in Kronenberger et al., 2012b, and more than 400 in Ampithoe rubricata, N. Neretin, unpublished data), and the cell size is also minimal in Dyopedos bispinis. These facts might reflect small body size of the White Sea Dyopedos bispinis compared with other studied amphipods.

\section{Secretion ultrastructure}

The secretory granule ultrastructure is similar in the studied species (Dyopedos bispinis, Ampithoe rubricata, and Crassicorophium bonellii, Kronenberger et al., 2012b; Neretin, 2016); granules of proximal gland groups are electron dense and have a normal, round shape (Fig. 6D, H, and Fig. 7C-D), unlike distal group granules (Fig. 8B-E). 
A

B
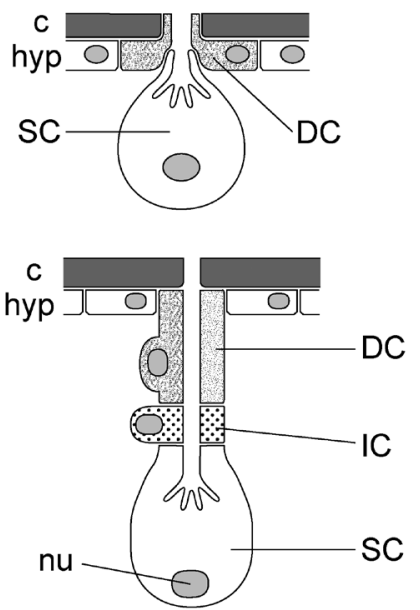

E

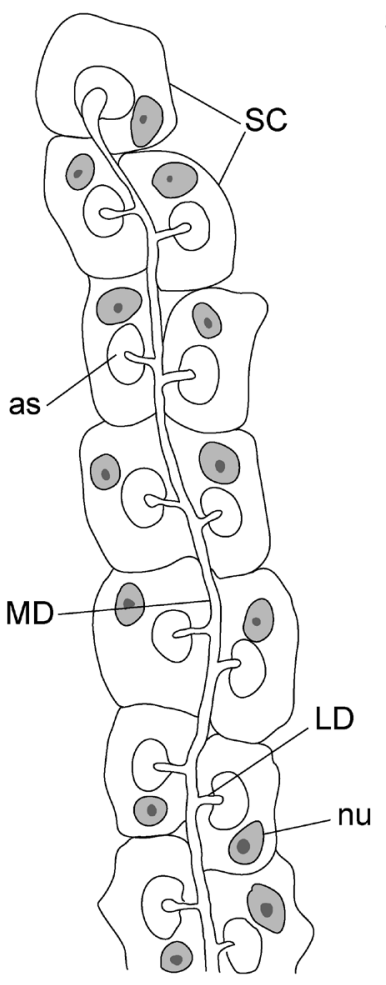

C

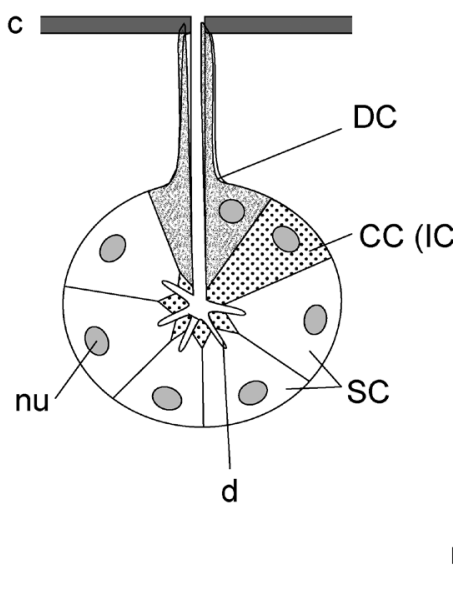

D
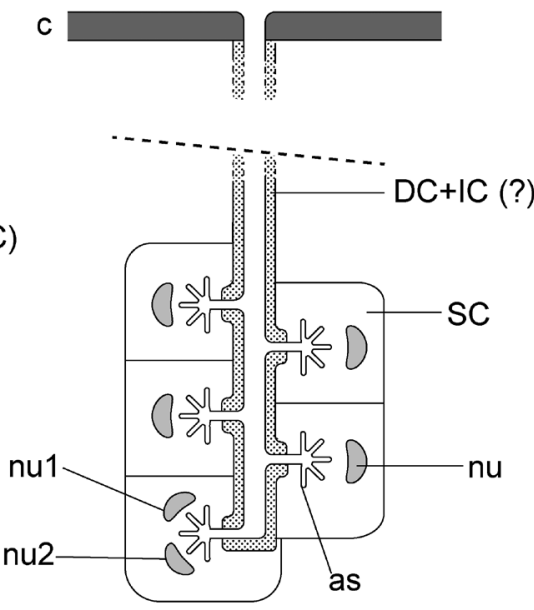

G

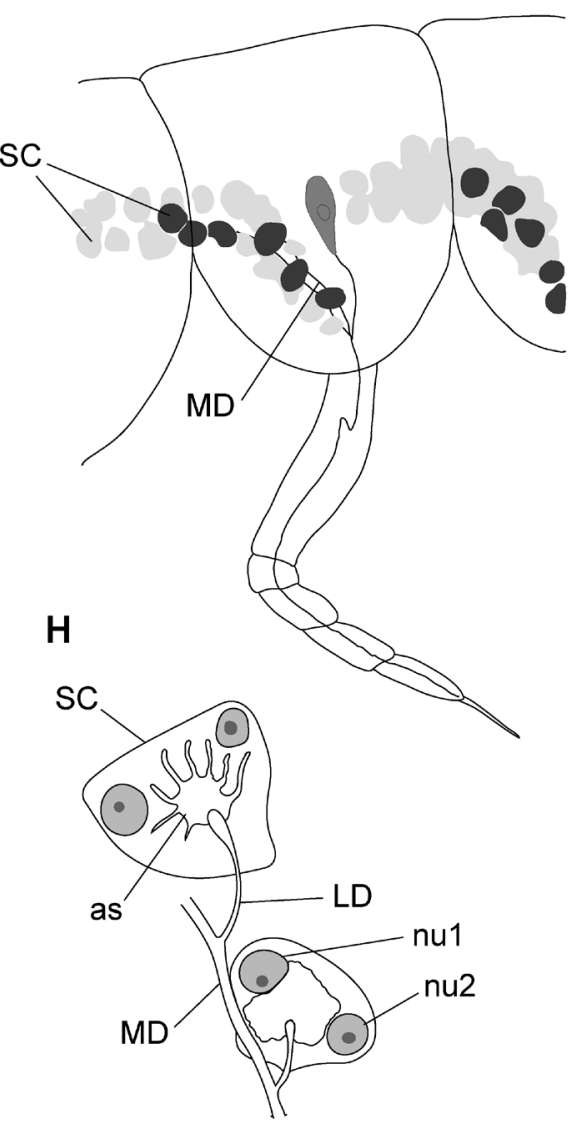

Fig. 9. Comparative schematic drawings of Dyopedos bispinis proximal glands (D1) and other crustacean tegumental glands. A, B and C - several types of crustacean tegumental glands modified from Talbot and Demers, 1993 and Rieder, 1977: A - bicellular glands, B - tricellular glands, C - rosette glands; D, E and F - pseudotubular silk glands of Amphipoda: D - A. rubricata (after Neretin, 2016), E - J. falcata (modified from Nebeski, 1880), F - Dyopedos bispinis; G and H - tube-building glands of the tanaid H. oerstedii (Kroyer 1842) (after Blanc, 1884), also likely pseudotubular; I - cirripedian cement glands (modified from Lacombe and Liguori, 1969). Abbreviations: as - accumulation site; $\mathrm{c}$ - cuticle; CC - central cell; DC - duct cell; hyp - hypoderm; IC - intermediary cell; LD - lateral duct; MD - main duct; nu, nu1 and nu2 - nucleuses of secretory cells; SC - secretory cell; ySC - young secretory cells. 
The distal glands of Dyopedos bispinis may produce several different substances because D2 secretory cells contain different types of granules (Fig. 8D). Two morphologically different types of granules are presented in Ampithoe rubricata distal glands (Neretin, 2016), and only uniform granules are found in Crassicorophium bonellii distal glands (Kronenberger et al., 2012b).

\section{Secretion for tube and mast building summary}

In general, we did not detect any crucial differences in the glandular complex structure and forms of secretions in tube-building species and the mast-builder $D y$ opedos bispinis. The variability in the dwellings most likely reflects behavioural adaptations.

\section{Morphology of amphipod silk glands compared with other crustacean glands}

\section{Secretory cell nucleus quantity}

Dyopedos bispinis D1 and D2 secretory cells are uninucleate (Fig. 6A), as are the silk glands of the majority of other amphipod species (Jassa falcata, Jassa ocia (Bate, 1862), Crassicorophium crassicorne (Bruzelius, 1859), Ericthonius punctatus (Bate, 1857), and Ampithoe ramondi Audouin, 1826) (Nebeski, 1880)). However, in Ampithoe rubricata glands, binuclear secretory cells have also been observed together with uninucleate cells (Neretin, 2016). The basis glands in the pereopods of Crassicorophium bonellii are also binuclear according to the drawing by Kronenberger et al. (2012b).

Binuclearity is typically regarded as a prominent feature of lobed glands (Talbot and Demers, 1993) and is occasionally used as a diagnostic character (Kakui and Hiruta, 2014). However, the secretory cells in lobed glands contain one or two nucleuses, apparently independent of cell size (Gorvett, 1951). Furthermore, it was recently shown that binuclear cells, together with uninuclear cells, occur in isopod rosette glands (Vittori et $a l ., 2012)$. Thus, variations in nuclear number are present in different types of crustacean tegumental glands but are currently only described within Percarida (Isopoda, Tanaidacea, Amphipoda) and not in Decapoda. It is likely that similar variations also occur in Mystacocarida (Elofsson and Hessler, 2005).

\section{Gland lining}

In Dyopedos bispinis, the proximal silk glands (D1) are covered with a lining layer (Fig. 6C, E and Fig. 7). We cannot unambiguously determine whether the lining is a part of the duct cell or an independent structure. Thus, we can only hypothesize as to its origin.

The presence of nuclei favours the independence of the lining cell from other gland cells (duct and secretory). The cellular layer covering the glands, which is classified as connective tissue, has been described in many crustaceans: decapod (Yong, 1932; Pugh, 1962) and isopod (Ide, 1891; Gorvett, 1946) rosette glands, cirripedian cement glands (Lacombe and Liguory, 1969), amphipod Ampithoe rubricata silk glands (Neretin, 2016) and isopod lobed glands (Ide, 1891; Gorvett, 1951), but the fallacy of this interpretation for lobed glands was observed in a study by Weirich and Ziegler (1997).

The lining could also represent a system of branching extensions of the duct (or intermediate) cell, and such systems have been described for intermediate cells in lobed (tricellular, Weirich and Ziegler, 1997) and rosette (Vittori et al., 2012) glands of isopods. In Dyopedos bispinis, this hypothesis is supported by the fact that, in some places, the lining comprises numerous cytoplasmic extensions (arrowheads, Fig. 7E) that deeply penetrate secretory cell invaginations (i, Fig. 7A-D), as in lobed glands. However, branches of intermediate cells in the isopod glands serve to collect secretions on the basal surface of secretory cells (Weirich and Ziegler, 1997). In contrast, the D1 gland cell secretion is excreted through the apical cell membrane, as evidenced by the presence of a definitely visible accumulation site (as, Fig. 6).

The lining might be considered an enlarged sheath cell, thus sharing a common origin with the duct cell. Sheath cells are typically observed in arthropod sensilla and at some stages of insect dermal gland development (Quennedey, 1998; Merritt, 2006).

The lining might also be a complex structure; for example, nervous terminations are likely located in this region as previously assumed for isopod lobed glands (Wägele, 1992). To understand the nature of the lining, more detailed electron microscopy investigations are required.

\section{Gland innervation}

The observation of an axon-like structure (Fig. 6F) in contact with the secretory cell likely indicates the presence of nervous control of amphipod silk glands. Gland innervation has been demonstrated in the branchial rosette glands of the decapod Palaemonetes pugio Holthuis, 1949 (Doughtie and Rao, 1982), in the labrum glands of the cladoceran Daphnia obtusa Kurz, 1874 emend Scourfield, 1942 (Zeni and Zaffagnini, 1988), in 
cirripedian cypris larva glands (Okano et al., 1996), and in mystacocarid tegumental glands (Elofsson and Hessler, 2005). However, crustacean tegumental glands are not typically innervated (Talbot and Demers, 1993). For amphipod silk glands, innervation was shown for the first time in the present study.

\section{Cellular composition of Dyopedos bispinis proximal amphipod silk glands}

Each proximal gland (D1) contains some (up to 17) secretory cells and one duct cell with an intracellular duct. Insect glands contain duct cells with an intercellular duct, which are referred to as class 3 glands (Noirot and Quennedey, 1974) or dermal glands, in contrast with unicellular and tubular glands (Merritt, 2006). In contrast to typical insect class 3 glands (Noirot and Quennedey, 1974; Quennedy, 1998), the secretory cells of the D1 glands do not have microvilli in the ductule lumen. D1 duct cells also do not have a mesaxon, which is the cross connection between the inner and outer duct cell membranes and has been described in many insect and crustacean dermal glands (Lai-Fook, 1970; Martens, 1979; Lawrence and Staddon, 1975; Doughtie and Rao, 1982; Elofsson and Hessler, 1998; Lombardo et al., 2006; Vittori et al., 2012).

Dermal glands are common in Arthropoda and contain one to two consecutive duct cells and one or several secretory cells (Quennedy, 1998; Coons and Alberti, 1999; Hilken et al., 2005; Pekár and Šobotník, 2007, Müller et al., 2014). The dermal glands of the Crustacea contain one to two secretory cells, which are referred to as bicellular (Fig. 9A) or tricellular (Fig. 9B) depending on the quantity of duct cells (Talbot and Demers, 1993, Elofsson and Hessler, 1998; Zeni and Stagni, 2000). In Malacostraca, rosette dermal glands (Fig. 9C) are also widely distributed, and each are composed of two duct cells (in the narrow sense, duct and intermediate) and multiple (up to 40-50) secretory cells (Talbot and Demers, 1993).

The proximal silk glands (D1) of Dyopedos bispinis (Fig. 6 and Fig. 9F) contain some secretory cells and appear similar to rosette glands, but D1 glands, at least at first glance, have two significant differences. First, we have observed only one (not two) duct cell in each gland. Glands comprising single duct cells and several secretory cells have been described in Crustacea (Claus, 1879; Ide, 1891; Gorvett, 1946; Pugh, 1962), but there are no electron microscopy studies confirming this "bicellular" scheme. Thus, we propose that the boundary between the duct and intermedium cell might be difficult to detect on semi-thin sections and might not be captured on ultrathin sections due to the significant length of the duct (up to $2 \mathrm{~mm}$ ).

Second, D1 glands markedly differ in shape from typical rosette glands. Rosette glands are typically globular; ductules from secretory cells coalesce at approximately one point (Johnson and Talbot, 1987; Alexander, 1989; Talbot and Demers, 1993, Fig. 9C). In contrast, D1 glands are strongly elongated, and ducts from secretory cells fall individually and sequentially into the main duct. However, occasionally, rosette glands might also be slightly elongated (Ide, 1891; Pugh, 1962) or even have practically tubular forms (recently described terrestrial hermit crab Coenobita spp. antennal glands, Tuchina et al., 2014). Dyopedos bispinis D1 glands even have more elongated, almost cord-like forms (Fig. 5B, 9F), and such gland morphology has not been incorporated into the Talbot and Demers (1993) classification of crustacean tegument glands. If typical rosette glands are similar to the typical acinar glands of metazoans (Ide, 1891), then Dyopedos bispinis D1 glands resemble rather tubular glands. We propose that such glands can be called pseudotubular.

\section{Comparison with other arthropod silk glands}

Glands similar in shape to D1 have been described within silk-producing systems in other corophiid amphipod species (Fig. 9D-E) (Nebeski, 1880; Neretin, 2016) and in the tanaid Heterotanais oerstedii (Krøyer, 1842) (Fig. 9G-H) (Blanc, 1884), all of which might be defined as pseudotubular. Building glands in other crustaceans suggest another structure; the amphipods Crassicorophium bonellii and Lembos websteri and the tanaid Phoxokalliapseudes tomiokaensis (Shiino, 1966) have lobed and typical rosette glands (Kronenberger et al., 2012b, Kakui and Hiruta, 2014), while callianassid shrimps (Decapoda) have only typical rosette glands (Dworschak, 1998). Cirripedian cement glands are multicellular but do not possess special duct cells (Lacombe and Liguori, 1969) and might be considered tubular gland variations (class 1 glands, according to the Noirot and Quennedey classification, 1974).

Silkworms and spiders, the most famous silk-producers, have classical tubular glands (Sehnal and Akai, 1990), but there is some evidence of homology between spider ampullate silk glands and sensilla (Hilbrant and Damen, 2015). In insects, dermal glands are homologous to sensilla (Quennedey, 1998; Merritt, 2006), and it can be assumed that spider silk glands passed through the dermal gland stage during evolutionary development. Futhermore, there is an assumption, that insect labial silk glands originate from der- 
mal glands, but it is questionable (Kenchington, 1969; Sutherland et al., 2010).

Dermal (class 3) silk glands are common among insects (Sutherland et al., 2010); these glands are bicellular or tricellular (according to "crustacean" terminology) and typically numerous. However, multicellular dermal silk glands are unknown in insects (although secretory cells can be multinucleated, Nagashima et al., 1991). Thus, the pseudotubular silk glands of amphipods and, likely, tanaids are probably unique among arthropod silk glands as these structures are tubular in shape, although indeed dermal.

\section{Pseudotubular gland origin}

We propose that the pseudotubular glands of Dyopedos bispinis could originate from increasing secretion in conjunction with space limitations in narrow appendages. Multicellular gland enlargement could occur at the expense of elongation and growth towards the proximal part of the appendage. In the hermit crab, Coenobita spp., elongated antennal glands also probably appeared as a result of a great increase in secretion production volume (Tuchina et al., 2014).

Coenobita spp. antennal glands likely appear as modified rosette glands (Tuchina et al., 2014). Dyopedos bispinis D1 glands could also have evolved from typical rosette glands, particularly as these glands have been observed in amphipods (Schmitz, 1967, 1992).

\section{Conclusions}

Dyopedos bispinis occasionally shows a more complex social structure than other corophiids: masts are occasionally not individual but collective dwellings. The prerequisites for the appearance of this trait might be (1) the possibility of several individuals successfully coexisting and (2) the possibility of continuous reinforcement of the dwelling.

Mast-building dulichiids are involved in multiple interactions with fouling organisms, so in Dyopedos bispinis, most masts are attached to other animals, which can be partly or fully immured.

Masts occasionally have a complex structure. One mast can have several central cylinders covered by a common cortex, and several supports or, in contrast, can branch (following hydroid immuration).

We did not detect any crucial differences in the glandular complex structure of tube-building species and the mast-builder Dyopedos bispinis. The variability in the dwellings most likely reflects behavioural ad- aptations; large masts are potentially supported by continuous growth and collective building.

Amphipod silk glands of Dyopedos bispinis and many other amphipods have an unusual structure in comparison with other crustacean glands, so we refer to them as "pseudotubular" glands. They are multicellular, strongly elongated type-3 glands (according to Noirot and Quennedey, 1974) that comprise optionally binuclear secretory cells, a duct cell and a lining of uncertain origin.

\section{Acknowledgements}

This study was supported by grants 15-29-02447, 15-04-00259 and 16-04-00343 from the Russian Foundation of Basic Research. The transmission electron microscopy investigations were supported by the Russian Scientific Foundation, grant 1450-00029. The authors would like to thank Elsevier Language Editing Services for editing the English throughout the manuscript, G.A. Kolbasov (N. Pertzov White Sea Biological Station, MSU) for critically reading the manuscript, and J. Bishop (Kuwait Institute for Scientific Research) and S. Garushyants (Institute for Information Transmission Problems, Moscow) for English language editing of sections of the text. The authors would also like to thank G.N. Davidovich, A.G. Bogdanov, and V. Rileeva (Laboratory of Electron Microscopy, MSU) for SEM assistance; S.I. Metelev (Laboratory of Electron Microscopy, I. Papanin Institute of Biology of Internal Waters) and E.V. Vortsepneva (Department of Invertebrate Zoology, MSU) for TEM assistance; and L.V. Ilyash, T.A. Belevich, and I.G. Radchenko (Department of Hydrobiology, MSU) for assistance with diatom identification. Moreover, the authors thank A.A. Semenov (WSBS dive station, MSU) for assistance with the organization of the diving trips and for providing some of the underwater photos; I.A. Kosevich and N.M. Biserova (Department of Invertebrate Zoology, MSU) for assistance with the treatment of the study materials; V.A. Spiridonov (P. Shirshov Institute of Oceanology) for participating in the work planning; and D.A. Ozerov, G.D. Kolbasova, and B.V. Osadchenko (WSBS and the Invertebrate Zoology Department, MSU) for assistance at different stages of this study. Finally, we like to thank two reviewers, Martin Thiel (Universidad Católica del Norte, Chile) and one anonymous reviewer, for their constructive remarks. Their input is highly valued.

\section{References}

Alexander C. 1989. Tegumental glands in the paragnaths of $\mathrm{Pa}$ laemon serratus (Crustacea: Natantia). Journal of the Marine Biological Association of the United Kingdom 69(1): 53-63. http://dx.doi.org/10.1017/S0025315400049109

Altman GH, Diaz F, Jakuba C, Calabro T, Horan RL, Chen J, Lu H, Richmond J, Kaplan DL. 2003. Silk-based biomaterials. Biomaterials 24(3): 401-416. http://dx.doi.org/10.1016/S0142-9612(02) 00353-8 
Atkinson RJA, Eastman LB. 2015. Burrow dwelling in Crustacea. Pp. 100-140 in: Thiel M, Watling L, ed., The Natural History of the Crustacea, Volume 2: Lifestyles and Feeding Biology. New York: Oxford University Press. http://dx.doi.org/10.1111/zoj.12326

Barnard JL, Thomas JD, Sandved KB. 1988. Behavior of gammaridean Amphipoda: Corophium, Grandidierella, Podocerus, and Gibberosus (American Megaluropus) in Florida. Crustaceana. Supplement, 13: 234-244.

Blanc H. 1884. Contribution a l'histoire naturelle des Asellotes Hétéropodes, observations faites sur la Tanais ærstedii, Krœr. Pp. 189-258, pl. 10-12 in Fol H, ed., Recueil zoologique Suisse. Serie 1 1. Genève, Bâle: Georg H.

Cadien DB. 2015. Amphipoda of the Northeast Pacific (Equator to Aleutians, intertidal to abyss): XXVIII. Ampeliscoidea an updated review. Southern California Association of Marine Invertebrate Taxonomists (SCAMIT). URL: http:// www.scamit.org/tools/toolbox-new/ARTHROPODA/ Subphylum\%20Crustacea/Class\%20Malacostraca/Sub class\%20Eumalacostraca/Superorder\%20Peracarida/Order \%20Amphipoda/-OTHER\%20USEFUL\%20TOOLS/NEP $\% 20$ Amphipod $\% 20$ Reviews/Amphipoda $\% 20$ of $\% 20$ the $\% 20$ NEP\%20Ampeliscoidea.pdf.

Cerda O, Hinojosa IA, Thiel M. 2010. Nest-building behavior by the amphipod Peramphithoe femorata (Krøyer) on the kelp Macrocystis pyrifera (Linnaeus) C. Agardh from northerncentral Chile. The Biological Bulletin 218(3): 248-258. http://dx.doi.org/10.1086/BBLv218n3p248

Claus C. 1879. Der Organismus der Phronimiden. Pp. 59-146 in: Claus C, ed., Arbeiten aus dem Zoologischen Instituten der Universität Wien und der Zoologischen Station in Triest 2. Wien: Alfred Hölder.

Coons LB, Alberti G. 1998. Exocrine glands. Pp. 296-328 in Coons LB, Alberti G Chapter 5. Acari: Ticks, in Harrison FW, Foelix RF, ed., Microscopic anatomy of invertebrates, Volume 8B, Chelicerate Arthropoda. New York, Chichester, Weinheim, Briabane, Singapore, Toronto: Wiley-Liss.

Dixon I, Moore PG. 1997. A comparative study on the tubes and feeding behaviour of eight species of corophioid Amphipoda and their bearing on phylogenetic relationships within the Corophioidea. Philosophical Transactions of the Royal Society of London B: Biological Sciences 352(1349): 93-112. http://dx.doi.org/10.1098/rstb.1997.0006

Doughtie DG, Rao KR. 1982. Rosette glands in the gills of the grass shrimp, Palaemonetes pugio. I. Comparative morphology, cyclical activity, and innervation. Journal of Morphology 171(1): 41-67. http://dx.doi.org/10.1002/jmor.1051710104

Duffy JE. 2002. The ecology and evolution of eusociality in sponge-dwelling shrimp. In: Kikuchi T, ed., Genes, Behavior, and Evolution in Social Insects. Sapporo: University of Hokkaido Press.

Duffy JE. 2007. Ecology and Evolution of Eusociality in SpongeDwelling Shrimp. Pp. 387-412 in: Duffy JE, Thiel M, ed., Evolutionary Ecology of Social and Sexual Systems: Crustaceans as Model Organisms. New York: Oxford University Press. http://dx.doi.org/10.1093/acprof:o so/9780195179927.001.0001

Dworschak PC. 1998. The role of tegumental glands in burrow construction by two Mediterranean callianassid shrimp. Senckenbergiana maritima 28: 143-149.

http://dx.doi.org/10.1007/BF030 43145
Elofsson R, Hessler RR. 1998. Tegumental glands of Hutchinsoneilla macracantha (Cephalocarida). Journal of Crustacean Biology 18(1): 42-56. http://dx.doi.org/10.1163/193724098X00052

Elofsson R, Hessler RR. 2005. The tegumental glands of Derocheilocaris typica (Crustacea, Mystacocarida). Arthropod Structure \& Development 34(2): 125-138. http://dx.doi.org/10.1016/j.asd.2004.12.001

Foelix RF. 2011. Spider silk. Pp. 136-140 in Foelix RF, Biology of spiders. New York: Oxford University Press.

Goodhart C. 1939. Notes on the bionomics of the tube building amphipod, Leptocheirus pilosus Zaddach. Journal of the Marine Biological Association of the United Kingdom 23: 311-325. http://dx.doi.org/10.1017/S0025315400013916

Gorvett H. 1946. The tegumental glands in the land Isopoda, the rosette glands. The Quarterly journal of microscopical science 87: 209-235.

Gorvett H. 1951. The Tegumental Glands in the Land Isopoda B. The Lobed Glands: Structure and Distribution. Quarterly Journal of Microscopical Science 92: 275-296.

Hilbrant M, Damen WG. 2015. The embryonic origin of the ampullate silk glands of the spider Cupiennius salei. Arthropod structure \& development 44(3): 280-288. http://dx.doi.org/10.1016/j.asd.2015.04.001

Hilken G, Rosenberg J, Brockmann C. 2005. Ultrastructure of the epidermal maxilla II-gland of Scutigera coleoptrata (Chilopoda, Notostigmophora) and the ground pattern of epidermal gland organs in Myriapoda. Journal of Morphology 264(1): 53-61. http://dx.doi.org/10.1002/jmor.10317

Ide M. 1891. Glandes cutanées a canaux intracellulaires chez les crustacés édriophthalmes. Pp. 345-372, pl. I-II in: Carnoy JB, Gilson G, Denys J, ed., La Cellule 7. Lierre and Louvain: Typ. de Joseph Van in and C, Aug. Peeters Libraire.

Johnson B, Talbot P. 1987. Ultrastructural analysis of the pleopod tegumental glands in male and female lobsters, Homarus americanus. Journal of Crustacean Biology: 288301. http://dx.doi.org/10.2307/1548609

Kakui K, Hiruta C. 2014. Diverse pereopodal secretory systems implicated in thread production in an apseudomorph tanaidacean crustacean. Journal of morphology 275(9): 1041-1052. http://dx.doi.org/10.1002/jmor.20281

Kanneworff E, Nicolaisen W. 1972. The "Haps" a framesupported bottom corer. Ophelia 10(2): 119-128. http://dx.doi.org/10.1080/00 785326.1972.10430108

Kenchington W. 1969. Silk secretion in sawflies. Journal of Morphology 127(3): 355-362. http://dx.doi.org/10.1002/jmor.1051270306

Kovoor J. 1987. Comparative structure and histochemistry of silk-producing organs in arachnids. Pp. 160-186 in: Nentwig W, ed., Ecophysiology of spiders. Berlin Heidelberg New York London Paris Tokyo: Springer-Verlag. http://dx.doi.org/10.1007/978-3-642-71552-5_12

Kronenberger K, Dicko C, Vollrath F. 2012a. A novel marine silk. Naturwissenschaften 99(1): 3-10. http://dx.doi.org/10.1007/s00114-011-0853-5

Kronenberger K, Moore PG, Halcrow K, Vollrath F. 2012b. Spinning a marine silk for the purpose of tube-building. Journal of Crustacean Biology 32(2): 191-202. http://dx.doi.org/10.1163/193724011X615532 
Kundu B, Kurland NE, Bano S, Patra C, Engel FB, Yadavalli VK, Kundu SC. 2014. Silk proteins for biomedical applications: bioengineering perspectives. Progress in Polymer Science 39(2): 251-267.

http://dx.doi.org/10.1016/j.progpolymsci.2013.09.002

Lacombe D, Liguori VR. 1969. Comparative histological studies of the cement apparatus of Lepas anatifera and Balanus tintinnabulum. Biological Bulletin 137(1): 170-180. http://dx.doi.org/10.2307/1539940

Lai-Fook J. 1970. The fine structure of developing type 'B' dermal glands in Rhodnius prolixus. Tissue and Cell 2(1): 119-138. http://dx.doi.org/10.1016/S0040-8166(70)80011-8

Lawrence P, Staddon B. 1975. Peculiarities of the epidermal gland system of the cotton stainer Dysdercus fasciatus Signoret (Heteroptera: Pyrrhocoridae). Physiological Entomology 49(2): 121-136. http://dx.doi.org/10.1111/j.1365-3032.1975tb00076.x

Laubitz DR. 1977. A revision of the genera Dulichia Krøyer and Paradulichia Boeck (Amphipoda, Podoceridae). Canadian Journal of Zoology 55(6): 942-982. http://dx.doi.org/10.1139/z77-123

Lincoln RJ. 1979. British Marine Amphipoda: Gammaridea. Pp. 1-658. London: British Museum (Natural history).

Lombardo B, Fanciulli P, Grasso R, Cicconardi F, Caruso D, Dallai R. 2006. Fine structure of the secretory and sensory organs on the cephalon and the first pereionite of Trichoniscus alexandrae Caruso (Crustacea, Isopoda). Tissue and Cell 38(2): 99-110. http://dx.doi.org/10.1016/j.tice.2005.12.005

Martens J. 1979. Feinstruktur der Tarsal-Drüse von Siro duricovius (Joseph) (Opiliones, Sironidae). Zoomorphologie 92(1): 77-93. http://dx.doi.org/10.1007/BF00999836

Mattson S, Cedhagen T. 1989. Aspects of the behaviour and ecology of Dyopedos monacanthus (Metzger) and Dyopedos porrectus Bate, with comparative notes on Dulichia tuberculata Boeck (Crustacea: Amphipoda: Podoceridae). Journal of Experimental Marine Biology and Ecology 127(3): 253-272. http://dx.doi.org/10.1016/0022-0981(89)90078-6

Meadows PS, Reid A. 1966. The behaviour of Corophium volutator (Crustacea: Amphipoda). Journal of Zoology 150(4): 387-399. http://dx.doi.org/10.1111/j.1469-7998.1966. tb03013.x

McCloskey LR. 1970. A new species of Dulichia (Amphipoda, Podoceridae) commensal with a sea urchin. Pacific Science 24: 90-98. http://dx.doi.org/10125/4031

Merritt DJ. 2006. The organule concept of insect sense organs: sensory transduction and organule evolution. Advances in Insect Physiology 33: 192-241. http://dx.doi.org/10.1016/S0065-2806(06)33004-4

Moore P, Earll R. 1985. Sediment "whips”: Amphipod artefacts from the rocky sublittoral in Britain. Journal of experimental marine biology and ecology 90(2): 165-170. http://dx.doi.org/10.1016/0022-0981(85)90117-0

Moore PG, Eastman LB. 2015. The tube-dwelling lifestyle in crustaceans and its relation to feeding. Pp. 57-99 in: Thiel M, Watling L, ed., The Natural History of the Crustacea, Volume 2: Lifestyles and Feeding Biology. http://dx.doi.org/10.1111/zoj.12326

Myers AA, Lowry JK. 2003. A phylogeny and a new classification of the Corophiidea Leach, 1814 (Amphipoda). Journal of Crustacean Biology 23(2): 443-485.

http://dx.doi.org/10.1163/20021975-99990353
Müller CH, Rosenberg J, Hilken G. 2014. Ultrastructure, functional morphology and evolution of recto-canal epidermal glands in Myriapoda. Arthropod structure \& development 43(1): 43-61. http://dx.doi.org/10.1016/j. asd.2013.08.001

Nagashima T, Niwa N, Okajima S, Nonaka T. 1991. Ultrastructure of silk gland of webspinners, Oligotoma japonica (Insecta, Embioptera). Cytologia 56(4): 679-684. http://dx.doi.org/10.1508/cytologia.56.679

Nebeski O. 1880. Beiträge zur Kenntniss der Amphipoden der Adria. Pp. 111-162, pl. 1-2 in Claus C., ed., Arbeiten aus dem Zoologischen Institut der Universität zu Wien 3. Wien: Alfred Hölder.

Neretin NY. 2016, in press. The morphology and ultrastructure of "amphipod silk" glands in Ampithoe rubricata (Crustacea, Amphipoda, Ampithoidae). Biology Bulletin 43(7): 1-15.

Noirot C, Quennedey A. 1974. Fine structure of insect epidermal glands. Annual review of entomology 19(1): 61-80. http://dx.doi.org/10.1146/annurev.en.19.010174.000425

Okano K, Shimizu K, Satuito C, Fusetani N. 1996. Visualization of cement exocytosis in the cypris cement gland of the barnacle Megabalanus rosa. Journal of experimental biology 199(10): 2131-2137.

Pekár S, Šobotník J. 2007. Comparative study of the femoral organ in Zodarion spiders (Araneae: Zodariidae). Arthropod structure \& development 36(2): 105-112. http://dx.doi.org/10.1016/j.asd.2006.08.005

Pugh JE. 1962. A contribution toward a knowledge of the hindgut of fiddler crabs (Decapoda, Grapsidae). Transactions of the American Microscopical Society 81(4): 309-320. http://dx.doi.org/10.2307/3223780

Quennedey A. 1998. Insect epidermal gland cells: ultrastructure and morphogenesis. Pp. 177-208 in Harrison FW, Locke M, ed., Microscopic anatomy of invertebrates, Volume 11A, Insecta. New York Chichester Weinhelm Brisbane Singapore Toronto: Wiley-Liss.

Rieder N. 1977. Ultrastruktur und funktion der hautdrusen von Triops cancriformis Bose (Crustacea, Notostraca). Zoomorphologie 88: 133-143. http://dx.doi.org/10.1007/ BF01880650

Schmitz EH. 1967. Visceral anatomy of Gammarus lacustris lacustris Sars (Crustacea: Amphipoda). American Midland Naturalist: 78(1): 1-54. http://dx.doi.org/10.2307/2423369

Schmitz EH. 1992. Chapter 10: Amphipoda. Pp. 443-528 in Harrison FW, Humes AG, ed., Microscopic anatomy of invertebrates, Volume 9, Crustacea. New York Chichester Brisbane Toronto Singapore: Wiley-Liss.

Sehnal F, Akai H. 1990. Insect silk glands: their types, development and function, and effects of environmental factors and morphogenetic hormones on them. International Journal of Insect Morphology and Embryology 19(2): 79-132. http://dx.doi.org/10.1016/0020-7322(90)90022-H

Shillaker R, Moore P. 1978. Tube building by the amphipods Lembos websteri Bate and Corophium bonnellii Milne Edwards. Journal of Experimental Marine Biology and Ecology 33(2): 169-185. http://dx.doi.org/10.1016/0022-0981(78)90006-0

Skutch AF. 1926. On the Habits and Ecology of the Tube-Building Amphipod Amphithoe rubricata Montagu. Ecology 7(4): 481-502. http://dx.doi.org/10.2307/1931173

Smith SJ. 1874. Tube building Amphipoda. American Journal of 
Science and Arts, (Ser. 3) 7(42): 601-601.

Sutherland TD, Young JH, Weisman S, Hayashi CY, Merritt DJ. 2010. Insect silk: one name, many materials. Annual review of entomology 55: 171-188.

http://dx.doi.org/10.1146/annurev-ento-112408-085401

Talbot P, Demers D. 1993. Tegumental glands of Crustacea. Pp. 151-191 in Horst MN, Freeman JA, ed., The Crustacean Integument: Morphology and Biochemistry. Boka Raton, Ann Arbor, London, Tokyo: CRC Press.

Thiel M. 1997. Reproductive biology of an epibenthic amphipod (Dyopedos monacanthus) with extended parental care. Journal of the Marine Biological Association of the United Kingdom 77(04): 1059-1072. http://dx.doi.org/10.1017/S0025315400038625

Thiel M. 1998a. Extended parental care in marine amphipods. I. Juvenile survival without parents. Journal of Experimental Marine Biology and Ecology 227(2): 187-201. http://dx.doi.org/10.1016/S0022-0981(97)00268-2

Thiel M. 1998b. Population biology of Dyopedos monacanthus (Crustacea: Amphipoda) on estuarine soft-bottoms: importance of extended parental care and pelagic movements. Marine biology 132(2): 209-221. http://dx.doi.org/10.1007/s002270050387

Thiel M. 1999. Extended parental care in marine amphipods: II. Maternal protection of juveniles from predation. Journal of Experimental Marine Biology and Ecology 234(2): 235-253. http://dx.doi.org/10.1016/S0022-0981(98)00150-6

Thiel M. 2000. Population and reproductive biology of two sibling amphipod species from ascidians and sponges. Marine Biology 137(4): 661-674. http://dx.doi.org/10.1007/s002270000372

Thiel M. 2007. Social behavior of parent-offspring groups in crustaceans. Pp. 294-318 in: Duffy JE, Thiel M, ed., Evolutionary Ecology of Social and Sexual Systems: Crustaceans as Model Organisms. New York: Oxford University Press. http://dx.doi.org/10.1093/acprof:oso/9780195179927.001.0001

Thiel M. 2011. The evolution of sociality: peracarid crustaceans as model organisms. Pp. 285-298 in: Fransen C., Asakura A., ed., New Frontiers in Crustacean Biology Proceedings of the TCS Summer Meeting, Tokyo, 20-24 September 2009. Leiden: Koninklijke Brill NV. http://dx.doi.org/10.1163/ej.9789004174252.i-354.190

Tuchina O, Groh KC, Talarico G, Müller CH, Wielsch N, Hupfer Y, Svatoš A, Grosse-Wilde E, Hansson BS. 2014. Morphology and histochemistry of the aesthetasc-associated epidermal glands in terrestrial hermit crabs of the genus Coenobita (Decapoda: Paguroidea). PloS One 9(5): e96430. http://dx.doi.org/10.1371/journal.pone.0096430

Vittori M, Žnidaršič N, Štrus J. 2012. Microscopic anatomy of male tegumental glands and associated cuticular structures in Titanethes albus (Crustacea: Isopoda). Arthropod structure \& development 41(2): 133-144. http://dx.doi.org/10.1016/j.asd.2011.08.004

Wägele J. 1992. Chapter 11: Isopoda. Pp. 529-617 in Harrison FW, Humes AG, ed., Microscopic anatomy of invertebrates, Volume 9, Crustacea. New York, Chichester, Brisbane, Toronto, Singapore: Wiley-Liss.

Weirich D, Ziegler A. 1997. Uropod and lateral plate glands of the terrestrial isopod Porcellio scaber Latr. (Oniscidae, Crustacea): an ultrastructural study. Journal of Morphology 233(2): 183-193. http://dx.doi.org/10.1002/(SICI)10974687(199708)233:2<183::AID-JMOR7>3.0.CO;2-7

Wouters K, De Grave S. 1992. Redekea perpusilla De Vos, 1953 (Crustacea: Ostracoda: Paradoxostomatidae), First Record for the British Isles. The Irish Naturalists' Journal 24(1): 23-26.

Yonge CM. 1932. On the Nature and Permeability of Chitin. I. The Chitin Lining the Foregut of Decapod Crustacea and the Function of the Tegumental Glands. Proceedings of the Royal Society of London. Series B, Containing Papers of a Biological Character 111(772): 298-329.

Zeni C, Stagni A. 2000. Ducts of the labral glands of Leptestheria dahalacensis (Crustacea: Branchiopoda: Spinicaudata). Journal of morphology 246(2): 68-84. http://dx.doi.org/10.1002/1097-4687(200011)246:2<68::AIDJMOR3>3.0.CO;2-B

Zeni C, Zaffagnini F. 1988. Occurrence of innervation in labral glands of Daphnia obtusa (Crustacea, Cladocera). Journal of Morphology 198(1): 43-48. http://dx.doi.org/10.1002/jmor.1051980106

Zhadan AE, Tzetlin AB, Neretina TV, Kamenskaya OE, Mugue NS. 2006. Neisvestnie palochki (Unknown rods). Pp. 105108 in Tzetlin AB, Krasnova ED, Voronov DA, ed., Materiali X nauchnoi conferentsii BBS MGU, 9-10 august 2006 (Materials of $X$ scientific conference WSBS MSU, 9-10 august 2006). Moscow: Grif i K.

Zorn ME, Gingras MK, Pemberton SG. 2010. Variation in burrow-wall micromorphologies of select intertidal invertebrates along the Pacific Northwest coast, USA: behavioral and diagenetic implications. Palaios 25(1): 59-72. http://dx.doi.org/10.2110/palo.2009.p09-026r

Received: 5 september 2016

Revised and accepted: 2 March 2017

Published online: 18 July 2017

Editor: R. Vonk 